NBER WORKING PAPER SERIES

"UNFUNDED LIABILITIES" AND UNCERTAIN FISCAL FINANCING

Troy Davig

Eric M. Leeper

Todd B. Walker

Working Paper 15782

http://www.nber.org/papers/w15782

\author{
NATIONAL BUREAU OF ECONOMIC RESEARCH \\ 1050 Massachusetts Avenue \\ Cambridge, MA 02138 \\ February 2010
}

Prepared for the Carnegie-Rochester Conference Series on Public Policy, "Fiscal Policy in an Era of Unprecedented Budget Deficits," November 13-14, 2009. We thank our discussant, Kent Smetters, and the editor, Andy Abel, for suggestions that tightened the paper's arguments considerably and we thank Hess Chung, Alex Richter, and Shu-Chun S. Yang for helpful conversations. The views expressed herein are those of the authors and do notnecessarily represent those of the Federal Reserve Bank of Kansas City, the Federal Reserve System, or the National Bureau of Economic Research.

NBER working papers are circulated for discussion and comment purposes. They have not been peerreviewed or been subject to the review by the NBER Board of Directors that accompanies official NBER publications.

(C) 2010 by Troy Davig, Eric M. Leeper, and Todd B. Walker. All rights reserved. Short sections of text, not to exceed two paragraphs, may be quoted without explicit permission provided that full credit, including $\odot$ notice, is given to the source. 
"Unfunded Liabilities" and Uncertain Fiscal Financing

Troy Davig, Eric M. Leeper, and Todd B. Walker

NBER Working Paper No. 15782

February 2010

JEL No. E31,E6,E63,H6

\begin{abstract}
$\underline{\text { ABSTRACT }}$
We develop a rational expectations framework to study the consequences of alternative means to resolve the "unfunded liabilities" problem---unsustainable exponential growth in federal Social Security, Medicare, and Medicaid spending with no plan to finance it. Resolution requires specifying a probability distribution for how and when monetary and fiscal policies will change as the economy evolves through the 21st century. Beliefs based on that distribution determine the existence of and the nature of equilibrium. We consider policies that in expectation combine reaching a fiscal limit, some distorting taxation, modest inflation, and some reneging on the government's promised transfers. In the equilibrium, inflation-targeting monetary policy cannot successfully anchor expected inflation. Expectational effects are always present, but need not have large impacts on inflation and interest rates in the short and medium runs.
\end{abstract}

Troy Davig

Research Department

Federal Reserve Bank of Kansas City

Kansas City, MO 64198

Troy.Davig@kc.frb.org

Eric M. Leeper

Department of Economics

304 Wylie Hall

Indiana University

Bloomington, IN 47405

and NBER

eleeper@indiana.edu
Todd B. Walker

Department of Economics

105 Wylie Hall

Indiana University

Bloomington, IN 47405

walkertb@indiana.edu 


\title{
"Unfunded Liabilities" and Uncertain Fiscal Financing*
}

\author{
Troy Davig, Eric M. Leeper, and Todd B. Walker
}

\section{INTRODUCTION}

Profound uncertainty surrounds monetary and fiscal policy behavior in the United States. Even in normal times, the multiple objectives that guide Federal Reserve decisions and the absence of any mandates to guide federal tax and spending policies conspire to make it very difficult for private agents to form expectations of monetary and fiscal policies.

In the wake of the financial crisis and recession of 2007-2009, monetary and fiscal policies have not been normal and, as long-term projections by the Congressional Budget Office (CBO) make plain, in the absence of dramatic policy changes, policies are unlikely to return to normalcy for generations to come. Figure 1 reports actual and CBO projections of federal transfers due to Social Security, Medicaid, and Medicare as a percentage of GDP. Demographic shifts and rising relative costs of health care combine to grow these transfers from about 10 percent of GDP today to about 25 percent in 70 years. One much-discussed consequence of this growth is shown in figure 2, which plots actual and CBO projections of federal government debt as a share of GDP from 1790 to 2083. Relative to the future, the debt run-ups associated with the Civil War, World War I, World War II, the Reagan deficits, and the current fiscal stimulus are mere hiccups.

Of course, the CBO's projections are accounting exercises, not economic forecasts. The accounting embeds the assumption that current policies will remain in effect over the projection period. Because current policies have no provision for financing the projected transfers,

*February 19, 2010. Prepared for the Carnegie-Rochester Conference Series on Public Policy, "Fiscal Policy in an Era of Unprecedented Budget Deficits," November 13-14, 2009. We thank our discussant, Kent Smetters, and the editor, Andy Abel, for suggestions that tightened the paper's arguments considerably and we thank Hess Chung, Alex Richter, and Shu-Chun S. Yang for helpful conversations. Davig: Federal Reserve Bank of Kansas City, Troy.Davig@kc.frb.org; Leeper: Federal Reserve Bank of Kansas City, Troy.Davig@kc.frb.org; Walker: Indiana University, walkertb@indiana.edu. The views expressed herein are those of the authors and do not necessarily represent those of the Federal Reserve Bank of Kansas City or the Federal Reserve System. 


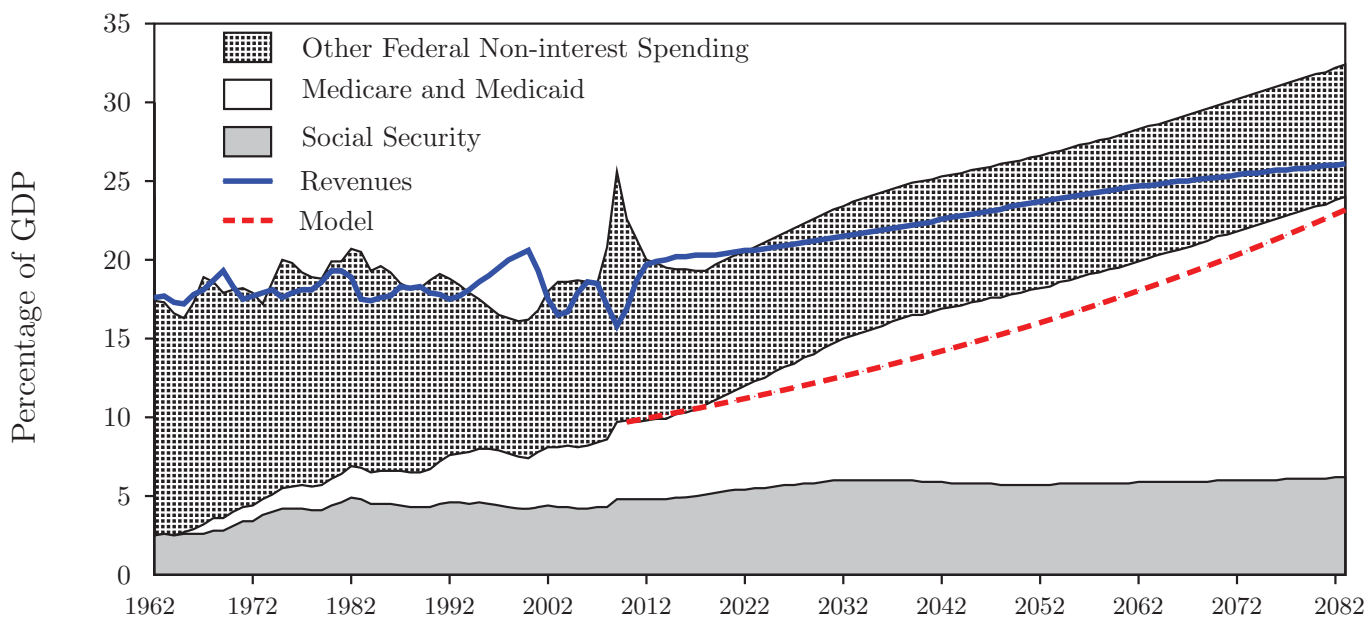

Figure 1: Projected and actual federal expenditures decomposed into Medicare, Medicaid, and Social Security spending and other non-interest spending. The solid line represents actual and projected revenues under the Extended-Baseline scenario. The dashed line is the calibration of the transfers process. See appendix A.1 for details. Source: Congressional Budget Office (2009b).

the accounting exercise converts those transfers into government borrowing, with no resulting adjustments in prices or economic activity.

What can we learn from figure 2? Very little because it depicts a scenario that cannot happen. In an economy populated by at least some forward-looking agents who participate in financial markets, long before an explosive trajectory for debt is realized, bond prices will plummet, sending long-term interest rates skyward. Why, even though the information contained in figures 1 and 2 has been known for many years, do investors continue to acquire U.S. government bonds bearing moderate yields? ${ }^{1}$ Evidently, financial market participants do not believe that current policies will continue indefinitely. That long-term interest rates are not rising steadily suggests that participants also seem not to believe that future policy adjustments are likely to generate substantial inflation in the near term.

Spending projections like figure 1 are difficult to rationalize in optimizing models without strong and implausible assumptions about information. ${ }^{2}$ There are several potential margins along which to rationalize the projections without abandoning the assumption that economic agents are well informed and forward looking. Either the expenditures will be financed somehow - agents expect that some policies will adjust to raise sufficient surpluses - or the implied "liabilities" in figure 2 are not liabilities - the government is expected to (partially) renege on its promises through "entitlements reforms." A third margin arises because the

\footnotetext{
${ }^{1}$ For example, the CBO has produced similar projections for well over a decade [O'Neill (1996), Congressional Budget Office (2002)] and economists like Auerbach and Kotlikoff had been discussing the "coming generational storm" long before Kotlikoff and Burns's (2004) book by that title appeared [(Auerbach and Kotilikoff, 1987, ch. 11), Auerbach, Gokhale, and Kotlikoff (1994, 1995)].

${ }^{2}$ Few public policy issues have received as much media attention, economic analysis, and political pontification as the periodic pronouncements of the bankruptcy of Social Security and the explosive growth in medical spending. Given the intense attention these issues have received, equilibria in which private agents are unaware of the problems arising from these transfers programs are wholly implausible.
} 


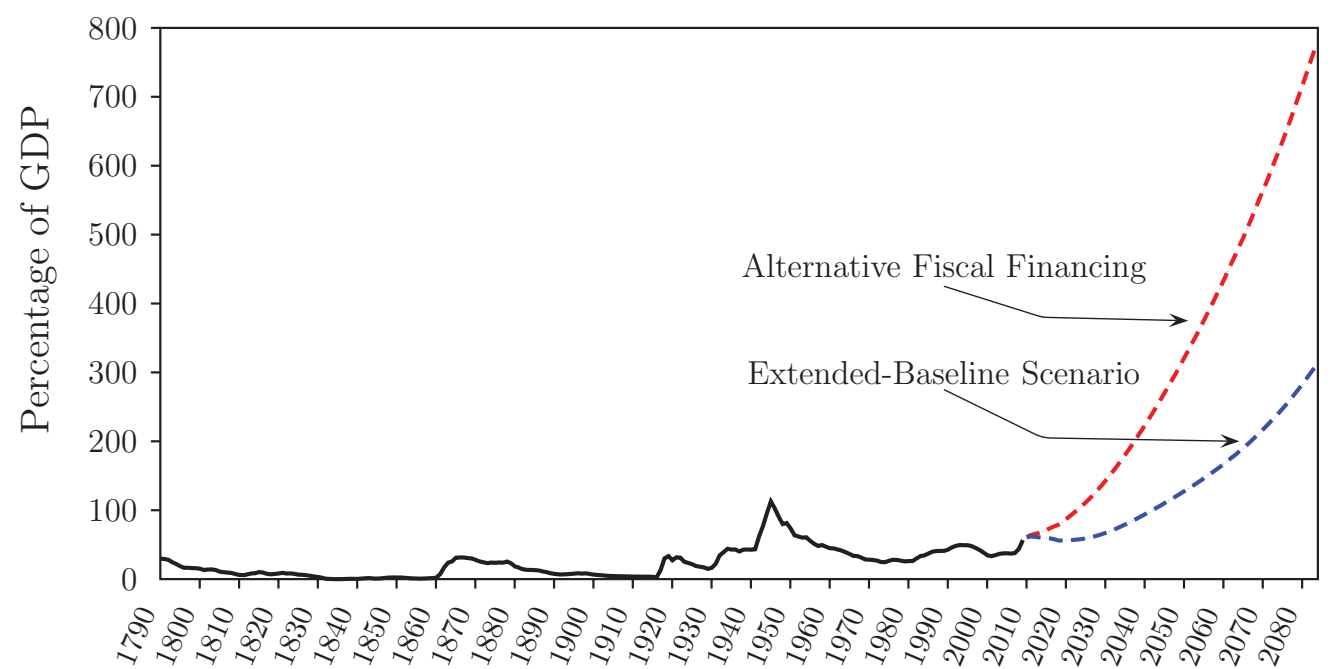

Figure 2: CBO's projections of Debt-to-GDP ratio under Alternative Fiscal and ExtendedBaseline Scenarios. See appendix A.1 for details.

bulk of U.S. government debt used to finance deficits is nominal: surprise price-level increases can revalue outstanding debt to be in line with the expected present value of surpluses.

American policy institutions do nothing to inform economic agents about which margins are likely to be exploited and when the policy adjustments will occur. Modeling the economic consequences of the uncertainty that uninformative policy institutions create is this paper's primary contribution.

1.1 Modeling Policy Uncertainty This paper develops a rational expectations framework to study an environment in which the government may be unwilling or unable to finance its entitlements commitments entirely through direct tax collections. The core model is a neoclassical growth economy with an infinitely lived representative household, capital accumulation, elastic labor supply, costly price adjustment, monetary policy, distorting taxes levied against labor and capital income, and a process describing the evolution of promised transfers from the government. By construction, the equilibrium is dynamically efficient so it is not feasible for the government to permanently rollover debt. Distorting taxes imply that there is a natural economic fiscal limit - the peak of the Laffer curve - to revenue growth. Spending commitments, like those depicted in figure 1, that grow exponentially cannot be financed entirely through direct taxes. How policies will adjust to be consistent with a rational expectations equilibrium is the crux of the model's uncertainty.

"Unfunded liabilities" is a term that gets bandied about in discussions of the U.S. fiscal position. Public finance economists and government agencies distinguish between prefunded and unfunded programs, where unfunded entails future funding, as in pay-as-you-go financing. By this definition, unfunded programs can be either sustainable or unsustainable. But the "unfunded liabilities" problem is a problem because of worries that future streams of revenues will be insufficient to support the projected expenditures - in other words, that current expenditure policies are not sustainable [Peter G. Peterson Foundation (2009)]. To connect to this alternative usage of the term, we use "unfunded" to mean that if current entitlements promises were to be honored, there would be insufficient surpluses to prevent an 
explosive path of federal debt.

Any study of long-term fiscal issues, including accounting exercises, is highly speculative, building in a great many tenuous assumptions about economic and policy developments many decades into the future. The discipline of general equilibrium analysis and rational expectations, however, requires still more speculation. For the exploding promised transfers path in figure 1 to be consistent with a rational expectations equilibrium, we must take stands on how policy may adjust in the future, the contingencies under which it may adjust, and how much economic agents know about those adjustments. But to move beyond hand-wringing about "unsustainable policies" and make progress on the macroeconomic consequences of alternative policy adjustments, we are compelled to take some such stands. This paper posits beliefs about policy adjustments that are consistent with equilibrium and it derives how those beliefs affect the evolution of the macro economy. Our aim is to describe potential policies and their consequences - not to prescribe particular policy solutions; neither do we examine the welfare implications of potential policies.

Into the neoclassical model we build several layers of uncertainty. The promised transfers process is stochastic and persistent, and initially follows a stationary process. At a random date, the transfers process switches to the explosive process labeled "Model" in figure 1, which is treated as an absorbing state for promised transfers. Both before and after the switch to the explosive transfers process, tax policy passively adjusts the distorting tax rate to try to stabilize government debt, while monetary policy is active, obeying a Taylor rule that aims to target the inflation rate. ${ }^{3}$ Over this period the promised transfers are funded by direct tax revenues and borrowing from the public.

If these policies were to persist indefinitely, with transfers growing as a share of GDP, the tax rate would eventually reach the peak of the Laffer curve. ${ }^{4}$ At this fiscal limit, tax revenues have reached their maximum and, with no financing help from the active monetary policy, government debt would take on the kind of explosive trajectory shown in figure 2. Rational agents would expect this outcome and refuse to accumulate debt that cannot be backed by future surpluses and seigniorage revenues. No equilibrium exists.

Although the peak of the Laffer curve is the economic fiscal limit, it is likely that in the United States the political limit will be reached at much lower tax rates. As the New York Times reports, "... Republicans refuse to talk about tax increases and Democrats refuse to talk about cutting entitlement programs..." [Sanger (2010)]. Ideally, the political fiscal limit would be ground out endogenously as a political economy equilibrium, which requires moving well outside our representative-agent environment. ${ }^{5}$ Instead, we model the vagaries

\footnotetext{
${ }^{3}$ Applying Leeper's (1991) definitions to a fixed-regime version of our model, "active" monetary policy targets inflation, while "passive" monetary policy weakly adjusts the nominal interest rate in response to inflation; "active" tax policy sets the tax rate independently of government debt and "passive" tax policy changes rates strongly enough when debt rises to stabilize the debt-GDP ratio; "active" transfers policy makes realized transfers equal promised transfers, while "passive" transfers policy allows realized transfers to be less than promised.

${ }^{4}$ A monetary economy may also have a Laffer curve for seigniorage revenues, as in Sargent and Wallace (1981). We do not allow for a distinct regime in which the printing press becomes an important revenue source because, like direct taxation, seigniorage cannot permanently finance growing transfers.

${ }^{5}$ In addition, general equilibrium models of political economy tend to predict outcomes sharply at odds with observed policy behavior; for example, sovereign debt defaults are predicted to occur either implausibly often or at implausibly low debt-GDP ratios on the order of 10 percent [Aguiar and Gopinath (2006), Arellano
} 
of the political system that grinds out the fiscal limit as an additional layer of uncertainty that has an endogenous component: as tax rates rise, agents place higher probability on hitting the limiting tax rate and inducing regime change, but the exact date of the change and the precise policies that will be adopted remain uncertain.

When tax rates reach their limit, they remain fixed and one of two possible regimes is realized: either the government partially reneges on its promised transfers, in effect making transfers policy passive, or monetary policy switches from being active to being passive, adjusting the nominal interest rate only weakly in response to inflation. At the fiscal limit, a random variable determines which policy becomes passive. Passive transfers policy is equivalent to entitlements reform; "unfunded liabilities" are no longer liabilities because the government chooses not to honor some fraction of its original promises. When monetary policy becomes passive, although realized transfers equal promised transfers, a different kind of reneging occurs as the price level jumps unexpectedly and the real value of outstanding government debt drops, in effect funding the liabilities.

After the economy reaches the fiscal limit, it never returns to a regime in which tax rates are adjusted to stabilize debt. Instead, the economy bounces randomly between the passive transfers regime and the passive monetary policy regime. So long as the probability of transiting to a passive transfers policy is positive, the economy can remain in the passive monetary policy regime indefinitely because expected transfers will remain below actual transfers.

1.2 What the Model Delivers We solve for a rational expectations equilibrium in which economic agents know the true probability distributions governing policy behavior and they observe current and past realizations of policy decisions, including the regimes that produce the policies. In contrast to much existing work on long-term fiscal policy, agents do not have perfect foresight and must form expectations over all possible future policy regimes. These expectations are what allow an equilibrium to exist, even in the presence of exploding promised government transfers. Expectations of possible future policy regimes also play an important role in determining the nature of equilibrium in the prevailing regime. Davig and Leeper $(2006,2007)$ show that the expectations formation effects that arise in some future regime can spill over into the current regime to produce equilibrium behavior that would not arise if only the current regime were possible.

Expectations about future adjustments in monetary and fiscal policies play a central role in creating sustainable policies. Long-run expectations, which are driven by beliefs about policy behavior beyond the fiscal limit, are anchored by the knowledge that policy will fluctuate between a regime in which debt is revalued through jumps in the price level and a regime in which the government may renege on its promised transfers. Because debt is expected to be stabilized in the long run, the pre-fiscal limit expansion in debt can be consistent with equilibrium.

Key findings include:

1. In an environment with exploding promised transfers, the conventional policy mixmonetary policy targets inflation and tax policy targets debt - cannot anchor private expectations on those policy targets. Before the economy has hit the fiscal limit, rising

(2008), Mendoza and Yue (2008)]. 
government debt raises tax rates and the probability of hitting the limit. As that probability rises, actual and expected inflation both increase. Failure of the usual mix to work in the usual way stems from sustainability considerations that create the expectation that policy regime will have to change in the future.

2. Expectational effects stemming from beliefs about future policy adjustments are ubiquitous, but need not have large impacts on inflation and real and nominal interest rates in the short to medium runs. Uncertainty about the fiscal limit and future policy adjustments serves to smooth the expectational effects.

Because changes in policy regime are intrinsically non-linear, we solve the full non-linear model numerically using the monotone map method. To ensure that the numerical solution is consistent with a rational expectations equilibrium, we check that the solution satisfies the transversality conditions associated with the underlying optimization problem. Before turning to that complex model, we develop intuition for the nature of the numerical solution by solving analytically a model that is considerably simpler.

\section{Contacts with the Literature}

One of the key contributions of the paper is to examine how uncertainty about fiscal and monetary policy can affect equilibrium outcomes. Sargent (2006) depicts policy uncertainty by replacing the usual probability triple, $(\Omega, \mathcal{F}, \mathcal{P})$, with $(?, ?, ?)$. He argues that the "prevailing notions of equilibrium" (i.e., exogenous state-contingent rules, time-inconsistent Ramsey problems, Markov-perfect equilibria, and recursive political equilibria) all assume agents have a complete description of the underlying uncertainty, while Knightian uncertainty or ambiguity about future policy might be a better description of reality. The agents in our model are rational and condition on a well specified probability triple. However, our model has several layers of uncertainty uncommon to the literature, which bridges the gap between a typical rational expectations model and the ideas of Sargent (2006).

The importance of understanding how uncertainty about monetary and fiscal policy shapes economic outcomes is obviously not a new concept. However, most of the early work introducing fiscal policy into modern dynamic general equilibrium models was conducted either in a non-stochastic environment or under the assumption that agents had perfect foresight [Hall (1971), Abel and Blanchard (1983)]. Bizer and Judd (1989) and Dotsey (1990) are among the first papers to model fiscal policy uncertainty in a dynamic general equilibrium framework. These papers emphasize the importance of uncertainty when examining welfare considerations, fiscal outcomes such as debt dynamics, and the behavior of investment, consumption, prices and interest rates. Like Bizer and Judd (1989) and Dotsey (1990), our paper argues for a more realistic stochastic process with respect to policy variables. We also find that adding important layers of uncertainty has profound effects on equilibrium.

In a series of papers, Auerbach and Hassett (1992, 2007), Hassett and Metcalf (1999) ask questions related to those posed here: What are the short-run and long-run economic effects of random fiscal policy? How does policy stickiness-infrequent changes in fiscal policy - affect investment and consumption decisions? With uncertainty about factors affecting fiscal variables, like demographics, what is the range of possible policy outcomes? The 
baseline model used by Auerbach, Hassett and Metcalf to answer some of these questions is a dynamic stochastic overlapping generations model with uncertain lifetimes and policy stickiness. Auerbach and Hassett (2007) find that introducing time-varying lifetime uncertainty and policy stickiness changes the nature of the equilibrium and of optimal policy dramatically. Our framework for addressing these questions is quite different. We re-interpret their concept of stickiness by assuming that several policy instruments can switch randomly according to a Markov chain. Instead of a one-time change in policy that is known, agents face substantial uncertainty about when policies will adjust and which policies will adjust. This allows for a broad range of potential policy outcomes, as advocated by Auerbach and Hassett.

One dimension in which our model suffers is that it does not take into account the important generational and distributional effects emphasized in Auerbach and Kotilikoff (1987), Kotlikoff, Smetters, and Walliser (1998, 2007), İmrohoroğlu, İmrohoroğlu, and Joines (1995), and Smetters and Walliser (2004). The canonical model used in these papers is an overlapping generations model with each cohort living for 55 periods. This model permits rich dynamics in demographics - population-age distributions, increasing longevity - intragenerational heterogeneity, bequest motives, liquidity constraints, earnings uncertainty, and so forth; this approach also allows for flexibility in modeling fiscal variables and alternative policy scenarios. Due to the richness and complexity of the model, only perfect foresight equilibria (or slight deviations from perfect foresight) are computed. A majority of the papers cited above analyze the distributional consequences of Social Security reform. ${ }^{6}$ While we cannot assess the distributional effects of alternative policies in our model, we substantially increase the complexity of the policy uncertainty faced by individuals.

The type of uncertainty we examine is similar in some respects to the institutional uncertainty described by North (1990, p. 83): "The major role of institutions in a society is to reduce uncertainty by establishing a stable (but not necessarily efficient) structure to human interaction. The overall stability of an institutional framework makes complex exchange possible across both time and space."

\section{The Full Model}

We employ a conventional neoclassical growth model with sticky prices, distorting income taxation, and monetary policy.

3.1 Housenolds An infinitely lived representative household chooses $\left\{C_{t}, N_{t}, M_{t}, B_{t}, K_{t}\right\}$ to maximize

$$
E_{t} \sum_{i=0}^{\infty} \beta^{i}\left[\frac{C_{t+i}^{1-\sigma}}{1-\sigma}-\chi \frac{N_{t+i}^{1+\eta}}{1+\eta}+\nu \frac{\left(M_{t+i} / P_{t+i}\right)^{1-\kappa}}{1-\kappa}\right]
$$

with $0<\beta<1, \sigma>0, \eta>0, \kappa>0, \chi>0$ and $\nu>0 . C_{t}=\left[\int_{0}^{1} c_{t}(j)^{\frac{\theta-1}{\theta}} d j\right]^{\frac{\theta}{\theta-1}}$ is a composite good supplied by a final-good producing firm that consists of a continuum of

\footnotetext{
${ }^{6}$ Volume 50 of the Carnegie-Rochester Conference Series on Public Policy published in 1999 was devoted to the sustainability of Social Security. Many of the papers published in that volume are similar in spirit to this paper. In particular, Bütler (1999) emphasizes the importance of modeling the uncertainty about the timing of policy changes.
} 
individual goods $c_{t}(j), N_{t}$ denotes time spent working, and $M_{t} / P_{t}$ are real money balances. The household's budget constraint is

$C_{t}+K_{t}+\frac{B_{t}}{P_{t}}+\frac{M_{t}}{P_{t}} \leq\left(1-\tau_{t}\right)\left(\frac{W_{t}}{P_{t}} N_{t}+R_{t}^{k} K_{t-1}\right)+(1-\delta) K_{t-1}+\frac{R_{t-1} B_{t-1}}{P_{t}}+\frac{M_{t-1}}{P_{t}}+\lambda_{t} z_{t}+\frac{D_{t}}{P_{t}}$,

where $K_{t-1}$ is the capital stock available to use in production at time $t, B_{t}$ is one-period nominal bond holdings, $M_{t}$ is nominal money holdings, $\tau_{t}$ is the distorting tax rate, $R_{t}^{k}$ is the real rental rate of capital, $R_{t-1}$ is the nominal return to bonds, $z_{t}$ are lump-sum transfers promised by the government, $\lambda_{t}$ is the fraction of promised transfers actually received by the household and $D_{t}$ is profits.

3.2 FIRMs There are two types of firms: monopolistically competitive intermediate goods producers who produce a continuum of differentiated goods and competitive final goods producers.

3.2.1 Production of Intermediate Goods Intermediate goods producing firm $j$ has access to a Cobb-Douglas production function, $y_{t}(j)=k_{t-1}(j)^{\alpha} n_{t}(j)^{1-\alpha}$, where $y_{t}(j)$ is output of intermediate firm $j$ and $k_{t-1}(j)$ and $n_{t}(j)$ are the amounts of capital and labor the firm rents and hires. The firm minimizes total cost, $w_{t} n_{t}(j)+R_{t}^{k} k_{t-1}(j)$, subject to the production technology.

3.2.2 Price SETting A final goods producing firm purchases intermediate inputs at nominal prices $P_{t}(j)$ and produces the final composite good using the following constantreturns-to-scale technology, $Y_{t}=\left[\int_{0}^{1} y_{t}(j)^{\frac{\theta-1}{\theta}} d j\right]^{\frac{\theta}{\theta-1}}$, where $\theta>1$ is the elasticity of substitution between goods. Profit-maximization by the final goods producing firm yields a demand for each intermediate good given by

$$
y_{t}(j)=\left(\frac{P_{t}(j)}{P_{t}}\right)^{-\theta} Y_{t}
$$

Monopolistically competitive intermediate goods producing firm $j$ chooses price $P_{t}(j)$ to maximize the expected present-value of profits

$$
E_{t} \sum_{s=0}^{\infty} \beta^{s} \Delta_{t+s} \frac{D_{t+s}(j)}{P_{t+s}}
$$

where, because the household owns the firms, $\Delta_{t+s}$ is the representative household's stochastic discount factor, $D_{t}(j)$ are nominal profits of firm $j$, and $P_{t}$ is the nominal aggregate price level. Real profits are

$$
\frac{D_{t}(j)}{P_{t}}=\left(\frac{P_{t}(j)}{P_{t}}\right)^{1-\theta} Y_{t}-\Psi_{t}(j)\left(\frac{P_{t}(j)}{P_{t}}\right)^{-\theta} Y_{t}-\frac{\varphi}{2}\left(\frac{P_{t}(j)}{\pi^{*} P_{t-1}(j)}-1\right)^{2} Y_{t},
$$

where $\varphi \geq 0$ parameterizes adjustment costs, $\Psi_{t}(j)$ is real marginal cost, and we have used the demand function in (2) to replace $y_{t}(j)$ in firm $j$ 's profit function. Price adjustment is 


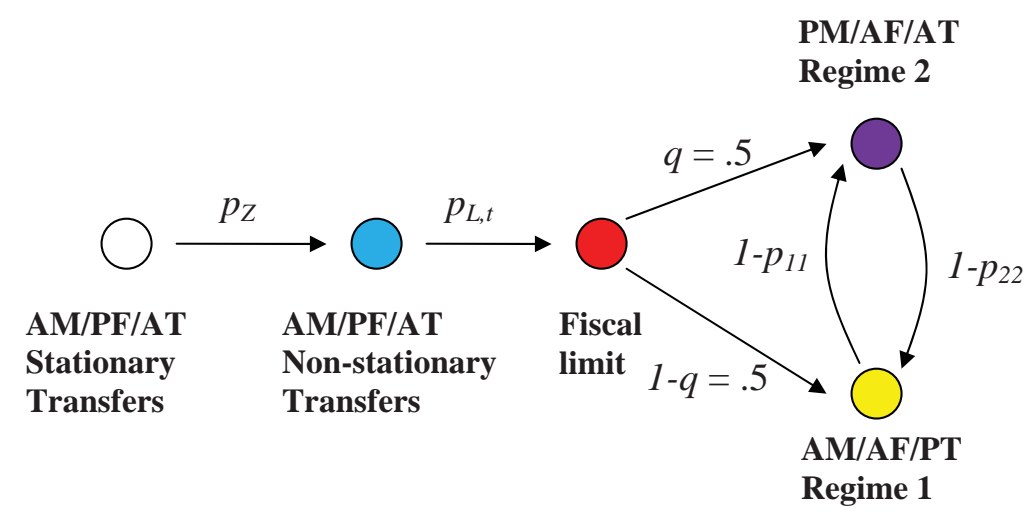

Figure 3: The unfolding of uncertainty about policy.

subject to Rotemberg (1982) quadratic costs of adjustment, which arise whenever the newly chosen price, $P_{t}(j)$, implies that actual inflation for good $j$ deviates from the steady state inflation rate, $\pi^{*}$. The first-order condition for the firm's pricing problem is

$$
\begin{aligned}
0= & (1-\theta) \Delta_{t}\left(\frac{P_{t}(j)}{P_{t}}\right)^{-\theta}\left(\frac{Y_{t}}{P_{t}}\right)+\theta \Delta_{t} \Psi_{t}\left(\frac{P_{t}(j)}{P_{t}}\right)^{-\theta-1}\left(\frac{Y_{t}}{P_{t}}\right)- \\
& \varphi \Delta_{t}\left(\frac{P_{t}(j)}{\pi^{*} P_{t-1}(j)}-1\right)\left(\frac{Y_{t}}{\pi^{*} P_{t-1}(j)}\right)+\beta E_{t}\left[\varphi \Delta_{t+1}\left(\frac{P_{t+1}(j)}{\pi^{*} P_{t}(j)}-1\right)\left(\frac{P_{t+1}(j) Y_{t+1}}{\pi^{*} P_{t}(j)^{2}}\right)\right] .
\end{aligned}
$$

In a symmetric equilibrium, every intermediate goods producing firm faces the same marginal costs, $\Psi_{t}$, and aggregate demand, $Y_{t}$, so the pricing decision is the same for all firms, implying $P_{t}(j)=P_{t}$. Steady-state marginal costs are given by $\Psi=(\theta-1) / \theta$, with $\Psi^{-1}=\mu$, where $\mu$ is the steady-state markup of price over marginal cost.

Note that in (4) the costs of adjusting prices subtracts from profits for firm $j$. In the aggregate, costly price adjustment shows up in the aggregate resource constraint as

$$
C_{t}+K_{t}-(1-\delta) K_{t-1}+G_{t}-\frac{\varphi}{2}\left(\frac{P_{t}(j)}{\pi P_{t-1}(j)}-1\right)^{2} Y_{t}=Y_{t}
$$

3.3 Fiscal Policy, Monetary Policy, and the Fiscal Limit Fiscal policy finances purchases, $g_{t}$, and actual transfers, $\lambda_{t} z_{t}$, with income tax revenues, money creation, and the sale of one-period nominal bonds. The government's flow budget constraint is

$$
\frac{B_{t}}{P_{t}}+\frac{M_{t}}{P_{t}}+\tau_{t}\left(\frac{W_{t}}{P_{t}} N_{t}+R_{t}^{k} K_{t-1}\right)=g_{t}+\lambda_{t} z_{t}+\frac{R_{t-1} B_{t-1}}{P_{t}}+\frac{M_{t-1}}{P_{t}} .
$$

We now describe the various layers of uncertainty surrounding tax, transfers, and monetary policies. Figure 3 describes schematically how the uncertainty unfolds. The fiscal authority sets promised transfers exogenously according to a Markov chain that starts with a stationary process for transfers, while monetary policy actively targets inflation, and tax policy raises tax rates passively when debt rises. The transfers process then switches, with 
probability $p_{Z}$, to a non-stationary process that is an absorbing state, mimicking the expotentially growing line labeled "Model" in figure 1. The transfers process, which operates for $t \geq 0$, is

$$
z_{t}= \begin{cases}\left(1-\rho_{z}\right) \bar{z}+\rho_{z} z_{t-1}+\varepsilon_{t} & \text { for } S_{z, t}=1 \\ \mu z_{t-1}+\varepsilon_{t} & \text { for } S_{z, t}=2\end{cases}
$$

where $z_{t}=Z_{t} / P_{t},\left|\rho_{z}\right|<1, \mu>1, \mu \beta<1, \varepsilon_{t} \sim N\left(0, \sigma_{z}^{2}\right) . S_{z t}$ follows a Markov chain, where the regime with exploding promised transfers is an absorbing state and $p_{z}$ denotes the probability of a switch to the non-stationary transfers regime. The expected number of years until the switch from the stationary to nonstationary regime is $\left(1-p_{z}\right)^{-1}$. In figure 3 the switch from the stationary to the non-stationary transfers policy occurs with probability $p_{z}$ and is marked by the move from the clear circle to the lightly shaded (blue) circle.

When transfers grow exponentially and are financed by new debt issuances, for some time taxes can rise to support the expanding debt. At some point, however, for economic reasonsreaching the peak of the Laffer curve - or political reasons - the electorate's intolerance of the distortions associated with high tax rates - tax policy will reach the fiscal limit. We model that limit as setting the tax rate to be a constant, $\tau_{t}=\tau^{\max }$ for $t \geq T$, where $T$ is the date at which the economy hits the fiscal limit. The setting of $\tau^{\max }$ is important for the long-run performance of the economy and, a priori, there is no obvious value for $\tau^{\max }$. One possibility is that tax rates settle at a relatively high value; but another equally plausible scenario is that taxpayers will revolt against high rates and $\tau^{\max }$ will be relatively low.

Tax policy sets rates according to

$$
\tau_{t}= \begin{cases}\tau^{*}+\gamma\left(\frac{B_{t-1} / P_{t-1}}{Y_{t-1}}-b^{*}\right) & \text { for } S_{\tau, t}=1, t<T \text { (Below Fiscal Limit) } \\ \tau^{\max } & \text { for } S_{\tau, t}=2, t \geq T \text { (Fiscal Limit) }\end{cases}
$$

where $b^{*}$ is the target debt-output ratio and $\tau^{*}$ is the steady-state tax rate.

The date at which the fiscal limit is hit, $T$, is stochastic. We posit that the probability at time $t, p_{L t}$, of hitting the fiscal limit is an increasing function of the tax rate at time $t-1$, implying that the probability rises with the level of government debt. A logistic function governs the evolution of the probability

$$
p_{L, t}=\frac{\exp \left(\eta_{0}+\eta_{1}\left(\tau_{t-1}-\bar{\tau}\right)\right)}{1+\exp \left(\eta_{0}+\eta_{1}\left(\tau_{t-1}-\bar{\tau}\right)\right)},
$$

where $\eta_{1}<0$. Households know the maximum tax rate, $\tau^{\max }$, but the precise timing of when that rate takes effect is uncertain.

Monetary policy behavior is conventional. It sets the short-term nominal interest rate in response to deviations of inflation from its target

$$
R_{t}=R^{*}+\alpha\left(\pi_{t}-\pi^{*}\right)
$$

where $\pi^{*}$ is the target inflation rate. Monetary policy is active when $\alpha>1 / \beta$, so policy satisfies the Taylor principle. Policy is passive when $0 \leq \alpha<1 / \beta$. 


\begin{tabular}{l|c|c|c} 
& AM/AF $/$ PT & & PM/AF /AT \\
\hline & Regime 1 & & Regime 2 \\
\hline & & & \\
$\mathrm{AM}:$ & $R_{t}=R^{*}+\alpha\left(\pi_{t}-\pi^{*}\right)$ & $\mathrm{PM:}$ & $R_{t}=R^{*}$ \\
$\mathrm{AF}:$ & $\tau_{t}=\tau^{\max }$ & $\mathrm{AF}:$ & $\tau_{t}=\tau^{\max }$ \\
$\mathrm{PT}:$ & $\lambda_{t} z_{t}$ & $\mathrm{AT}:$ & $z_{t}$
\end{tabular}

Table 1: AM: active monetary policy; PM: passive monetary policy; AF: active tax policy; AT: active transfers policy; PT: passive transfers policy.

Once the economy reaches the fiscal limit, tax policy is active, as it is no longer feasible to raise tax rates to finance further debt expansions. Because we take outright debt default off the table, some other policy adjustments must occur. Given active tax policy, we restrict attention to two possible policy regimes. One regime denoted AM/AF/PT, Regime 1 in table 1-has monetary policy actively targeting inflation, while transfers policy is passive, with the government (partially) reneging on its promised transfers by the fraction $\lambda_{t} \in[0,1]$. The other regime - denoted PM/AF/AT, Regime 2- has monetary policy abandoning the targeting of inflation by pegging the nominal interest rate at $R^{*}$, and an "active" transfers policy that sets actual transfers equal to promised transfers $\left(\lambda_{t}=1\right)$.

At the fiscal limit, the dark shaded (red) ball in figure 3 , households put equal probability on going to the two regimes in table $1, q=1-q=0.5$. Then policy bounces randomly between those two regimes, labeled in the figure Regimes 1 and 2, governed by the transition matrix

$$
\Pi_{T}=\left[\begin{array}{cc}
p_{11} & 1-p_{11} \\
1-p_{22} & p_{22}
\end{array}\right],
$$

where $p_{i i}$ is the probability of remaining in regime $i$ and $1-p_{i i}$ is the probability of moving from regime $i$ to regime $j$.

3.4 Calibration The parameters describing preferences, technology and price adjustment are set to be consistent with Rotemberg and Woodford (1997) and Woodford (2003). To study the impact of fiscal policy over a relatively long horizon, we calibrate the model at an annual frequency. Intermediate-goods producing firms set the price of their good 15 percent over marginal cost, implying $\mu=\theta(1-\theta)^{-1}=1.15$. For the price adjustment parameter, we set $\varphi=10$. If 66 percent of firms cannot reset their price each period, then a calibration at a quarterly frequency would suggest $\varphi$ would be around 70. Prices are certainly more flexible at an annual frequency, so the choice of $\varphi=10$ captures a modest price of cost adjustment. The annual real interest rate is set to 2 percent $(\beta=.98)$. Preferences over consumption and leisure are logarithmic, so $\sigma=1$ and $\eta=-1$. $\chi$ is set so the steady state share of time spent in employment is 0.33 . Steady state inflation is set to 2 percent and the initial steady state debt-output ratio is set to 0.4 .

For real balances, $\delta$ is set so velocity in the deterministic steady state, defined as $c P / M$, matches average U.S. monetary base velocity at 2.4. We take this value from Davig and Leeper (2006), based on data from 1959-2004 on the average real level of expenditures on non-durable consumption plus services. The parameter governing the interest elasticity of real money balances, $\kappa$, is set to 2.6 [Chari, Kehoe, and McGrattan (2000)]. 
Mean federal government purchases are set to a constant 8 percent share of output. In the stationary transfer regime, $\bar{z}$ is set to make steady state transfers 9 percent of output and the process for transfers is persistent, with $\rho_{Z}=.9$. Monetary policy is active in the stationary regime, where $\alpha=1.5$, and fiscal policy is passive, $\gamma=.15$. The inflation target is $\pi^{*}=2.0$. Steady state debt to output in this regime is set to .4, which determines $b^{*}$. This implies that $\bar{\tau}=.1980$, a value for the average tax rate in line with figure 1 . The expected duration of the stationary regime is five years $\left(p_{z}=.8\right)$, which is roughly the time before the CBO projects that transfers begin their upward trajectory. Transfers then grow at 1 percent per year once the switch from the stationary to non-stationary regime occurs, making $\mu=1.01$.

Once the economy switches to the regime with rising transfers, the same monetary and fiscal rules stay in place until the economy hits the fiscal limit. The probability of hitting the fiscal limit rises according to the logistic function (10), where $\eta_{0}$ and $\eta_{1}$ are set so that initially, the probability of hitting the fiscal limit is 2 percent. The probability then rises as debt and taxes rise, reaching roughly 20 percent by 2075, after which it rises rapidly.

At the fiscal limit, we assume tax rates are constant, $\tau^{\max }=.2425$. In the original stationary transfer state, this tax rate would support a steady state debt-output ratio of 2.3, an unprecedented level for the United States. However, with rising transfers, the level at which debt stabilizes is well below this. At the fiscal limit, higher tax rates are no longer available to stabilize debt, so we allow two potential resolutions, each with a 50 percent chance of being realized. The first resolution is a switch to passive monetary policy, where the monetary authority pegs the nominal interest rate $(\alpha=0)$ and the fiscal authority continues to make good on its promised transfers. The second resolution involves reneging on promised transfers payments. Under this scenario, monetary policy remains active. Each regime is calibrated to be persistent, where the expected duration of the passive monetary regime is 10 years and 100 years for the reneging regime.

\section{Some Analytical Intuition}

Before launching into the numerical solution of the complicated model in section 3, we highlight some of the mechanisms at work in the numerical solution with a simpler setup that admits an analytical solution. The setup is stark. It eliminates virtually all the uncertainty about future policies by assuming that the government's promised transfers always follow a non-stationary process and by positing that at some known future date, $T$, fiscal policy hits the fiscal limit and switches from passively adjusting lump-sum taxes to stabilize debt, to fixing tax revenues at their limit, $\tau^{\max }$. At date $T$, one of two possible policy combinations is pursued: either the government reneges on promised transfers or monetary policy becomes passive and pegs the nominal interest rate. Agents know which policy combination will be realized at $T$.

Consider a constant endowment economy that is at the cashless limit. A representative household pays lump-sum taxes, $\tau_{t}$, receives lump-sum transfers, $z_{t}$, and chooses sequences of consumption and risk-free nominal bonds paying gross nominal interest $R_{t},\left\{c_{t}, B_{t}\right\}$, to maximize $E_{0} \sum_{t=0}^{\infty} \beta^{t} u\left(c_{t}\right)$ subject to the budget constraint $c_{t}+B_{t} / P_{t}+\tau_{t}=y_{t}+z_{t}+$ $R_{t-1} B_{t-1} / P_{t}$, with $R_{-1} B_{-1}>0$ given. Government purchases are zero in each period so that goods market clearing implies $c_{t}=y_{t}=y$. In equilibrium the consumption Euler equation 
reduces to the simple Fisher relation

$$
\frac{1}{R_{t}}=\beta E_{t}\left(\frac{P_{t}}{P_{t+1}}\right)
$$

where $\beta \in(0,1)$ is the household's discount factor. With a constant endowment, the equilibrium real interest rate is also constant at $1 / \beta$.

We imagine that the government's promised transfers follow the non-stationary process given by (8), $z_{t}=\mu z_{t-1}+\varepsilon_{t}$, where $\mu>1, E_{t} \varepsilon_{t+1}=0$, and $z_{-1}>0$ is given. The process for promised transfers holds for all $t \geq 0$. The growth rate of transfers is permitted to be positive, but it must be bounded to ensure that $\mu \beta<1$. This restriction implies that transfers cannot grow faster than the steady state real interest rate.

Explosive growth in transfers implies that at some date $T$ in the future, the economy will reach the fiscal limit, beyond which households will be unwilling to hold additional debt and the government has reached its maximum capacity to levy taxes. This is not strictly true in this endowment economy with lump-sum taxes, but it would be true in a production economy with distorting taxation, such as the model in section $3 .^{7}$ Date $T$ is the period at which the tax rate reaches its fiscal limit, so that $\tau_{t}=\tau^{\max }$ for $t \geq T$, as in (9).

In the period before the economy reaches the fiscal limit, monetary policy is active and fiscal policy is passive. The rules are similar to those described in section 3 ,

$$
R_{t}^{-1}=R^{*-1}+\alpha\left(\frac{P_{t-1}}{P_{t}}-\frac{1}{\pi^{*}}\right), \quad \alpha>1 / \beta
$$

for monetary policy, where $\pi^{*}$ is the inflation target. Fiscal policy adjusts taxes passively to the state of government debt

$$
\tau_{t}=\tau^{*}+\gamma\left(\frac{B_{t-1}}{P_{t-1}}-b^{*}\right), \quad \gamma>r=1 / \beta-1
$$

where $b^{*}$ is the debt target.

The government's flow budget constraint is

$$
\frac{B_{t}}{P_{t}}+\tau_{t}=z_{t}+\frac{R_{t-1} B_{t-1}}{P_{t}}
$$

If policy rules (14) and (15) were to remain in effect forever, the promised transfers process were stationary, and there were no fiscal limit, this economy would exhibit Ricardian equivalence, with inflation determined only by parameters describing monetary policy behavior. But, with a non-stationary transfers process and a fiscal limit, such policy behavior, if agents believed it would remain in effect permanently, would produce an explosive path for government debt that, in finite time, would hit the fiscal limit and no equilibrium would exist. A rational expectations equilibrium requires that some policies adjust.

\footnotetext{
${ }^{7}$ In this model with lump-sum taxes there is no upper bound for taxes or debt, so long as debt does not grow faster than the real interest rate. But in a more plausible production economy, in which taxes distort behavior, there would be a natural fiscal limit. See Bi (2009) for an application of an endogenous fiscal limit to the issue of sovereign debt default.
} 
At the fiscal limit, $\tau_{t}=\tau^{\max }, t \geq T$, and monetary and transfers policies adjust. We examine two limiting cases. In the first, monetary policy continues to obey (14), but the government does not fully honor its promised transfers; instead, it delivers $\lambda_{t} z_{t}$, for $t \geq T$. In the second case, transfer promises are honored, $\lambda=1, t \geq T$, but monetary policy abandons the Taylor principle to simply peg the nominal rate at $R_{t}=R^{*}, t \geq T$.

4.1 A Reneging Regime Allowing the government to renege on promised transfers completely neutralizes the fiscal limit. If $\lambda_{t}$ is permitted to be negative, then transfers can exactly mimic the fiscal financing activities of lump-sum taxes and the economy exhibits Ricardian equivalence.

Modify the government budget constraint for periods $t \geq T$ to be $\frac{B_{t}}{P_{t}}+\tau^{\max }=\lambda_{t} z_{t}+$ $\frac{R_{t-1} B_{t-1}}{P_{t}}$, and set $\lambda_{t}=-\gamma b_{t-1} / z_{t}$ with $\gamma>r$, as in (15). Equilibrium inflation comes from combining (13) and (14) when monetary policy is active to yield

$$
\frac{\beta}{\alpha} E_{t}\left(\frac{P_{t}}{P_{t+1}}-\frac{1}{\pi^{*}}\right)=\frac{P_{t-1}}{P_{t}}-\frac{1}{\pi^{*}}
$$

Aggressive reactions of monetary policy to inflation imply that $\beta / \alpha<1$ and the unique bounded solution for inflation is $\pi_{t}=\pi^{*}$, so equilibrium inflation is always on target, as is expected inflation.

If monetary policy determines inflation and the path of the price level, $\left\{P_{t}\right\}$, how must fiscal policy respond to disturbances in transfers to ensure that policy is sustainable? This is where passive transfers adjustments step in. Substituting the tax rule, (15), into the government's budget constraint, taking expectations conditional on information at $t-1$, and employing the Fisher relation, (13), yields the expected evolution of real debt

$$
E_{t-1}\left(\frac{B_{t}}{P_{t}}\right)+\tau^{\max }=E_{t-1} \lambda_{t} z_{t}+\left(\beta^{-1}-\gamma\right)\left(\frac{B_{t-1}}{P_{t-1}}\right)
$$

Because $\beta^{-1}-\gamma<1$, higher debt brings forth the expectation of lower transfers, so (18) describes how debt is expected to return to steady state following a shock to $z_{t}$.

4.2 A Regime Where Monetary Policy Cannot Control Inflation Iterating forward on the government budget constraint and imposing both the household's transversality condition for debt accumulation and the household's Euler equation, we obtain the intertemporal equilibrium condition

$$
\frac{B_{0}}{P_{0}}=E_{0} \sum_{j=1}^{\infty} \beta^{j} s_{j}
$$

where $s_{t} \equiv \tau_{t}-z_{t}$ is the primary surplus.

To solve for this equilibrium we break the intertemporal equilibrium condition into two parts

$$
\frac{B_{0}}{P_{0}}=E_{0} \sum_{j=1}^{T-1} \beta^{j} s_{j}+E_{0} \sum_{j=T}^{\infty} \beta^{j} s_{j}
$$


where the function for the primary surplus, $s_{t}$, changes at the fiscal limit

$$
s_{t}= \begin{cases}\tau^{*}-\gamma\left(B_{t-1} / P_{t-1}-b^{*}\right)-z_{t}, & t=0,1, \ldots, T-1 \\ \tau^{\max }-z_{t}, & t=T, \ldots, \infty\end{cases}
$$

Expression (20) decomposes the value of government debt at the initial date into the expected present value of surpluses leading up to the fiscal limit and the expected present value of surpluses after the limit has been hit.

Evaluating the second part of $(20)$ and letting $\tau^{\max }=\tau^{*}$, after the limit is hit at $T$

$$
E_{0} \sum_{j=T}^{\infty} \beta^{j} s_{j}=E_{0}\left(\frac{B_{T-1}}{P_{T-1}}\right)=\frac{\beta^{T}}{1-\beta}\left(\tau^{*}-z^{*}\right)-\frac{(\beta \mu)^{T}}{1-\beta \mu}\left(z_{0}-z^{*}\right)
$$

The first part of (20) is a bit messier, as it involves solving out for the endogenous taxes that are responding to the state of government debt before the fiscal limit is hit. That part of (20) may be written as

$$
E_{0} \sum_{j=1}^{T-1} \beta^{j} s_{j}=\left(\tau^{*}-\gamma b^{*}-z^{*}\right) \sum_{j=1}^{T-1}\left(\frac{\beta}{1-\gamma \beta}\right)^{j}-\left(z_{0}-z^{*}\right) \sum_{j=1}^{T-1}\left(\frac{\beta \mu}{1-\gamma \beta}\right)^{j}
$$

Pulling together (22) and (23) yields equilibrium real debt at date $t=0$ as a function of fiscal parameters and the date 0 realization of transfers

$$
\begin{aligned}
\frac{B_{0}}{P_{0}} & =\left[\frac{\beta^{T}}{1-\beta}+\sum_{j=1}^{T-1}\left(\frac{\beta}{1-\gamma \beta}\right)^{j}\right]\left(\tau^{*}-z^{*}\right)-\gamma b^{*} \sum_{j=1}^{T-1}\left(\frac{\beta}{1-\gamma \beta}\right)^{j} \\
& -\left[\frac{(\beta \mu)^{T}}{1-\beta \mu}+\sum_{j=1}^{T-1}\left(\frac{\beta \mu}{1-\gamma \beta}\right)^{j}\right]\left(z_{0}-z^{*}\right)
\end{aligned}
$$

This expression determines the equilibrium value of debt. The value of debt at $t=0$ - and by extension at each date in the future - is uniquely determined by parameters describing preferences and fiscal behavior and by the exogenous realization of transfers at that date. We arrive at this expression by substituting out the endogenous sequence of taxes before the fiscal limit. Apparently this economy will not exhibit Ricardian equivalence even if tax policy obeys a rule that raises taxes to retire debt back to steady state. This occurs despite the fact that in the absence of a fiscal limit such a tax rule delivers Ricardian equivalence.

Two other implications are immediate. Higher transfers at time $0, z_{0}$, which portend a higher future path of transfers because of their positive serial correlation, reduce the value of debt. This occurs because higher expected government expenditures reduce the backing and, therefore, the value of government liabilities. A second immediate implication is more surprising. How aggressively tax policy responds to debt before hitting the fiscal limit, as parameterized by $\gamma$, matters for the value of debt. Permanent active monetary/passive tax policies, in contrast, produce Ricardian equivalence in this model, so the timing of taxation is irrelevant: how rapidly taxes stabilize debt has no bearing on the value of debt. Both of these unusual implications are manifestations of the breakdown in Ricardian equivalence 
that occurs when there is the prospect that at some point the economy will hit a fiscal limit, beyond which taxes will no longer adjust to finance debt. ${ }^{8}$

We now turn to how the equilibrium price level is determined. Given $B_{0} / P_{0}$ from (24) and calling the right side of $(24) b_{0}$, use the government's flow budget constraint at $t=0$ and the fact that $s_{0}=\tau_{0}-z_{0}$ to solve for $P_{0}$ :

$$
P_{0}=\frac{R_{-1} B_{-1}}{b_{0}+\tau_{0}-z_{0}}
$$

Given $R_{-1} B_{-1}>0,(25)$ yields a unique $P_{0}>0$. Entire sequences of equilibrium $\left\{P_{t}, R_{t}^{-1}\right\}_{t=0}^{\infty}$ are solved recursively: having solved for $B_{0} / P_{0}$ and $P_{0}$, obtain $R_{0}$ from the monetary policy rule and derive the nomimal value of debt. Then use (24) redated at $t=1$ to obtain equilibrium $B_{1} / P_{1}$ and the government budget constraint at $t=1$ to solve for $P_{1}$ using (25) redated at $t=1$, and so forth.

The equilibrium price level has the same features as it does under a fiscal theory equilibrium [Leeper (1991), Sims (1994), Woodford (1995), Cochrane (1999)]. Higher current or expected transfers, which are not backed in present-value terms by expected taxes, raise household wealth, increase demand for goods, and drive up the price level (reducing the value of debt). A higher pegged nominal interest rate raises nominal interest payments, raising wealth and the price level next period. Similarities between this equilibrium and those in the fiscal theory literature stem from the fact that price-level determination is driven by beliefs about policy in the long run. From $T$ on, this economy is identical to a fixed-regime passive monetary/active fiscal policies economy and it is beliefs about long-run policies that determine the price level. Of course, before the fiscal limit the two economies are quite different and the behavior of the price level will also be different.

In this environment where the equilibrium price level is determined entirely by fiscal considerations through its interest rate policy, monetary policy determines the expected inflation rate. Combining (13) with (14) we obtain an expression in expected inflation in periods $t<T$

$$
E_{t}\left(\frac{P_{t}}{P_{t+1}}-\frac{1}{\pi^{*}}\right)=\frac{\alpha}{\beta}\left(\frac{P_{t-1}}{P_{t}}-\frac{1}{\pi^{*}}\right)
$$

where $\alpha / \beta>1$.

Given equilibrium $P_{0}$ from (25) and an arbitrary $P_{-1}$ - arbitrary because the economy starts at $t=0$ and cannot possibly determine $P_{-1}$, regardless of policy behavior-(26) shows that $E_{0}\left(P_{0} / P_{1}\right)$ grows relative to the initial inflation rate. In fact, throughout the active monetary policy/passive fiscal policy phase, for $t=0,1, \ldots, T-1$, expected inflation grows at the rate $\alpha \beta^{-1}>1$. In periods $t \geq T$ monetary policy pegs the nominal interest rate at $R^{*}$, and expected inflation is constant: $E_{t}\left(P_{t} / P_{t+1}\right)=\left(R^{*} \beta\right)^{-1}=1 / \pi^{*}$.

The implications of the equilibrium laid out in equations (24), (25), and (26) for government debt, inflation, and the anchoring of expectations on the target values $\left(b^{*}, \pi^{*}\right)$ are most

${ }^{8}$ This is not to suggest that one cannot concoct "Ricardian scenarios." For example, because $T$ is known, if the government were to commit to fully finance the change in the present value of transfers that arises from a shock to $z_{0}$ before the economy reaches the fiscal limit, one could obtain a Ricardian outcome. But this is driven by the fact that $T$ is known. If $T$ were uncertain, as in the model in section 3 , with some probability of occurring at every date, even this cooked-up scenario would not produce a Ricardian result. 
clearly seen in a simulation of the equilibrium. Figure 4 contrasts the paths of the debtGDP ratio from two models: a fixed passive monetary/active tax regime - dashed line - and the present model in which an active monetary/passive tax regime is in place until the economy hits the fiscal limit at date $T$, when policies switch permanently to a passive monetary/active tax combination-solid line. ${ }^{9}$ The fixed regime displays stable fluctuations of real debt around the 50 percent steady state debt-GDP, which the other model also produces once it hits the fiscal limit. Leading up to the fiscal limit, however, it is clear that the active monetary/passive tax policy combination does not keep debt near target.

Expected inflation evolves according to (26). Leading up to the fiscal limit monetary policy is active, with $\alpha>1 / \beta$, and there is no tendency for expected inflation to be anchored on the inflation target. Figure 5 plots the inflation rate from the same fixed-regime modeldashed line - and from the present model - solid line - along with expected inflation from the present model-dotted dashed line. Inflation in the fixed regime fluctuates around $\pi^{*}$ and, with the pegged nominal interest rate, expected inflation is anchored on target. But in the period leading up to the fiscal limit, the price level is determined by the real value of debt, which as figure 4 shows, deviates wildly from its target, $b^{*}$. Expected inflation in that period, though not independent of the inflation target, is certainly not anchored by the target. Instead, under active monetary policy, the deviation of expected inflation from target grows with the deviation of actual inflation from target in the previous period. The figure shows how equation (26) makes expected inflation follow actual inflation, with active monetary policy amplifying movements in expected inflation.

Figures 4 and 5 also make the point that as the economy approaches the fiscal limit at date $T$, the equilibrium converges to the fixed-regime economy. This result is driven by the fact that date $T$ is known.

To underscore the extent to which inflation is unhinged from monetary policy, even in the active monetary/passive tax regime before the fiscal limit, suppose that tax policy reacts more aggressively to debt. A higher value of $\gamma$ in (15) can have unexpected consequences. Expression (24) makes clear that raising $\gamma$, which in a fixed active monetary/passive tax regime would stabilize debt more quickly, amplifies the effects of transfers shocks on debt. A more volatile value of debt, in turn, translates into more volatile actual and expected inflation.

An analogous exercise for monetary policy illustrates its impotence when there is a fiscal limit. A more hawkish monetary policy stance, higher $\alpha$ in (14), has no effect whatsoever on the value of debt and inflation: $\alpha$ does not appear in expression (24) for real debt or expression (25) for the price level. More hawkish monetary policy does, however, amplify the volatility of expected inflation.

Because monetary policy loses control of inflation after the fiscal limit it reached, forwardlooking behavior implies it also loses control of inflation before the fiscal limit is hit. By extension, changes in fiscal behavior in the period leading up to the limit affect both the equilibrium inflation process and the process for expected inflation.

\footnotetext{
${ }^{9}$ Figures 4 and 5 use the following calibration. Leading up to the fiscal limit, $\alpha=1.50$ and $\gamma=0.10$ and at the limit and in the fixed-regime model, $\alpha=\gamma=0.0$. We assume steady state values $\tau^{*}=0.19, z^{*}=0.17$, $\pi^{*}=1.02$ (gross inflation rate) and we assume $1 / \beta=1.04$ so that $b^{*}=0.50$. The transfers process has $\rho=0.90$ and $\sigma=0.002$. Identical realizations of transfers were used in all the figures.
} 


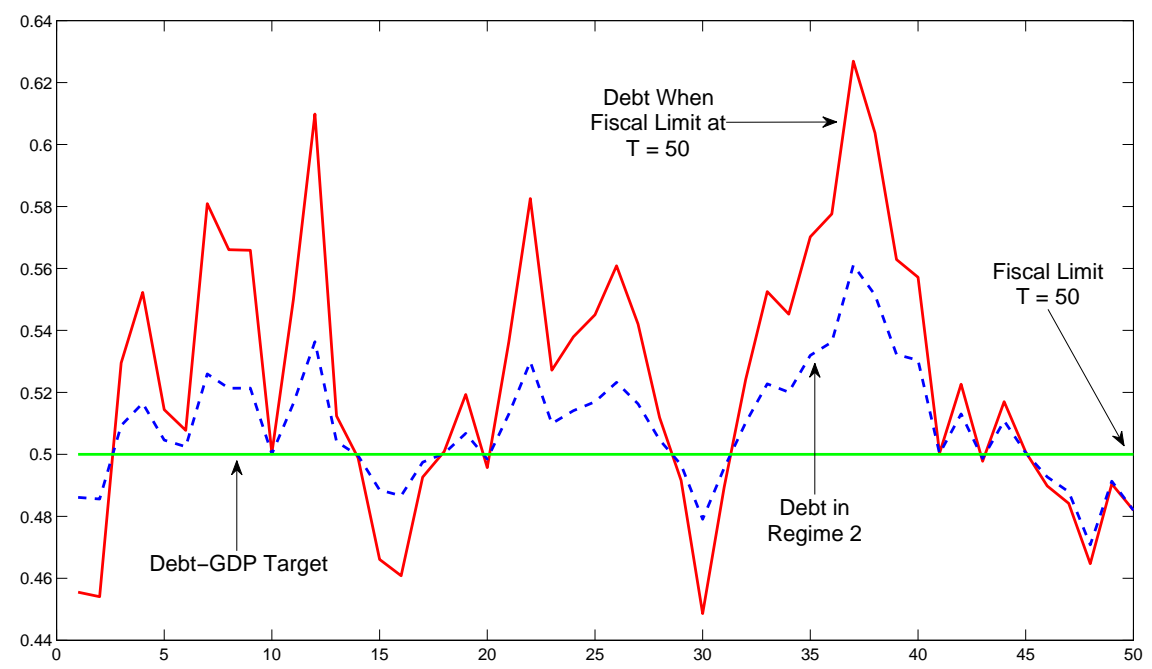

Figure 4: Debt-GDP ratios for a particular realization of transfers for two models: a fixed passive monetary/active tax regime - dashed line - and the present model in which an active monetary/passive tax regime is in place until the economy hits the fiscal limit at date $T$, when policy switch permanently to a passive monetary/active tax combination-solid line.

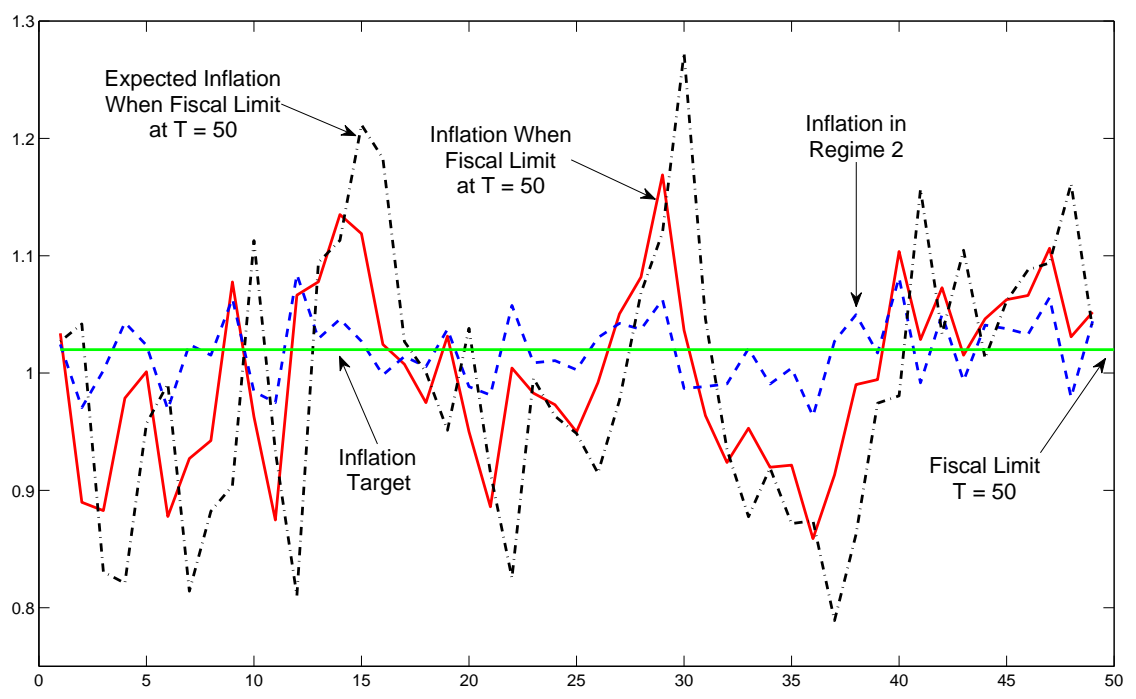

Figure 5: Inflation for a particular realization of transfers for two models: a fixed passive monetary/active tax regime - dashed line - and the present model in which an active monetary/passive tax regime is in place until the economy hits the fiscal limit at date $T$, when policy switch permanently to a passive monetary/active tax combination - solid line; expectation of inflation from present model-dotted dashed line. 


\section{Numerical Solution and Results}

We solve the model laid out and calibrated in section 3 using a nonlinear algorithm called the monotone path method described in Davig and Leeper (2006). That method discretizes the state space and finds a fixed point in decision-rules for each point in the state space. Details appear in appendix A.2.

This section reports results from the numerical solution. First, we show the transitional dynamics of the model for a particular realization of monetary-tax-transfers regimes. These dynamics highlight the critical role that expectations of future policies play in determining equilibrium. Then we perform a Monte Carlo exercise, taking draws from policy regimes according to the Markov processes described in section 3. This exercise yields the stationary distribution of the economy.

5.1 Transition Paths It is useful to condition on a particular realization of policy regimes and trace out how the equilibrium evolves following each type of regime change. Although in this counterfactual exercise we treat regimes as absorbing states, in the equilibria we study, agents form expectations based on the true probability distributions for policy regimes, as described in sections 3.3 and 3.4, and their decision rules embed those expectations. Expectations about policy regimes in the future can have strong effects on behavior in the prevailing regime. Because agents form expectations rationally, the counterfactual allows us to back out the expectational effects, which are reflected in sequences of forecast errors - policy surprises - that generate the dynamic adjustments along the transition paths. Realized policy regimes produce "shocks" to which agents in the model respond. ${ }^{10}$ One cautionary note: because these counterfactuals impose regime changes at arbitrary dates, rather than at dates governed by the underlying Markov processes, the counterfactuals are most useful for understanding qualitative features of the equilibrium. Quantitative features are discussed in the Monte Carlo exercise in section 5.2.

5.1.1 Active Monetary, Passive Tax, and Active Transfers Policies We imagine that the economy starts in 2010 in a regime characterized by active monetary policy, passive tax policy, and active (stationary) transfers policy and then switches in 2015 to an identical regime, but where transfers follow the non-stationary process, $S_{z, t}=2$ in expression (8). When transfers policy is active, the government makes good on its promised path of transfer payments. Transition paths shown in figure 6 condition on staying in the latter regime throughout the simulation.

Rising debt and the resulting rising tax rates are the dominant forces in this scenario. Steadily rising current and expected tax rates shift labor supply in, reducing hours worked, and discourage investment, reducing the capital stock below its 2009 steady-state level. Both consumption and output decline. As the tax rate rises, the probability of hitting the fiscal limit and switching to other policies also rises, according to the logistic function in (10).

The likelihood of moving to other regimes creates two expectational effects. First, while the date at which the fiscal limit kicks in is uncertain, agents know that at the limit the tax

\footnotetext{
${ }^{10}$ These are not identical to impulse response functions used to study linear models. In linear models, impulse response functions show the response of the economy to a one-time i.i.d. shock, with the path following the shocks being deterministic. In contrast, our counterfactuals create a sequence of shocks arising from what agents perceive to be surprise realizations of policy regimes.
} 

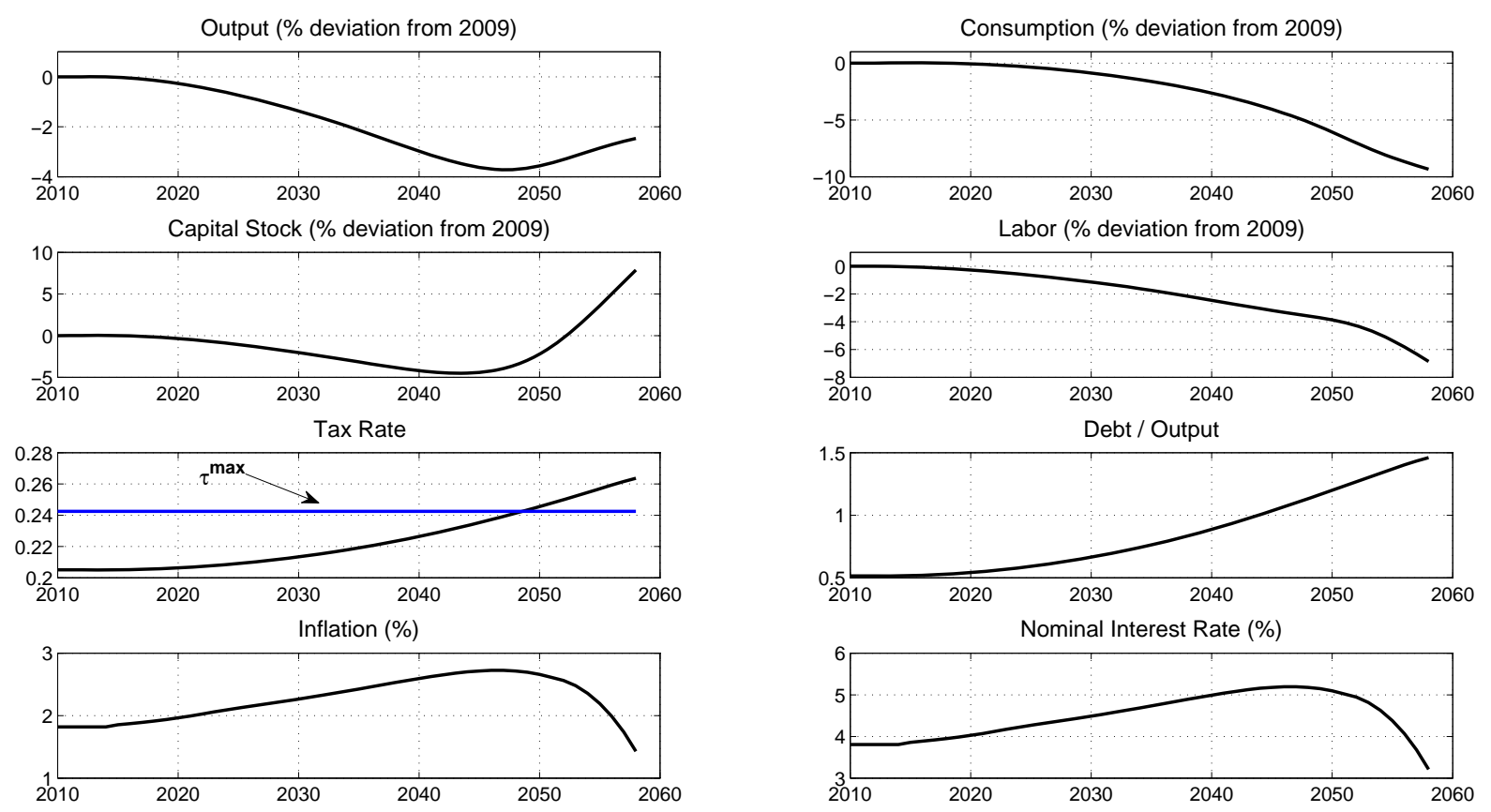

Figure 6: Transition paths conditional on remaining in the regime with active monetary, passive tax, and active transfers policies so the economy does not hit the fiscal limit.

rate will be permanently fixed at $\tau_{t}=\tau^{\max }$, which in the simulation is 0.2425 . When the current rate exceeds $\tau^{\max }$, agents expect lower rates in the future. Lower expected rates raise the expected return to capital, raising capital accumulation at the expense of consumption. This effect, however, does not kick in until about 2045 or later. Along the entire transition path tax policy is forced to remain passive, although agents put positive probability on hitting the limit. Since tax rates rise along with debt, labor also declines persistently.

The second expectational effect begins much sooner. Inflation rises in either of the two future regimes to which the economy moves after the fiscal limit. This creates higher expected inflation which has effects almost immediately, although they are small. Inflation in the model has two sources: higher expected inflation and higher real marginal costs. Marginal cost in the model depends on the ratio of each factor price to its marginal product. Over the horizon that inflation is rising in figure 6, real marginal cost is falling very gradually, which would tend to lower inflation, implying that expected inflation drives the steady rise in actual inflation. Although some of the increase in inflation is expected, over the period when inflation rises, agents are continually surprised by inflation.

This expected inflation effect is a more sophisticated version of the phenomenon that section 4 highlights. In the analytical example, the date of the fiscal limit is known, bringing the effects of expected future policies strongly into the present. In figure 6 the steady rise in inflation is driven by the steady rise in the probability of hitting the fiscal limit and switching to one of the other two regimes. A time-varying probability of reaching the fiscal limit translates directly into time-varying expected inflation.

Despite the sequence of positive inflation surprises before 2045, nominal government debt does not get revalued and stabilized. Active monetary policy prevents revaluation by 
adjusting the nominal interest rate more than one-for-one with inflation. In periods of rising (surprise) inflation, monetary policy effectively raises nominal debt service by more than the inflation rate, ensuring continued growth in debt.

The upturn in the capital stock that begins in 2045 is also driven by two distinct expectational effects. As mentioned, one is the expectation of lower tax rates in the future. Another expectational effect derives from the possibility of switching to the regime in which the government does not fully honor its promised transfers. Lower expected transfers encourage savings in the form of capital accumulation. A higher capital stock reduces its marginal product sufficiently that real marginal costs begin to decline. Although expected inflation continues to rise, the falling marginal costs eventually dominate, bringing inflation down quickly.

From figure 6 emerges a central message of the paper: in an environment in which fiscal policy is unwilling or unable to stabilize debt, monetary policy cannot successfully target inflation. The active monetary policy regime that prevails along the transition path responds aggressively to inflation with the aim of hitting a 2 percent inflation target. For over four decades it misses the target on the high side and then it misses the target on the low side. Both misses are due to expectational effects that are beyond control of the monetary authority in the current regime. Monetary policy loses control of inflation in an extreme form: it cannot control either actual or expected inflation, even though it is hawkishly targeting inflation.

5.1.2 Active Monetary, Active Tax, and Passive Transfers Policies This scenario and the next arise after the economy hits the fiscal limit - year 2047 in the simulationand tax rates are permanently set at $\tau^{\max }$. Unlike in the analytical model, in the numerical solution the economy does not then enter an absorbing state, as the two ultimate regimes recur randomly.

Leading up to 2047 the path of the economy is identical to that discussed in section 5.1.1. From 2047 on, tax policy is active - unresponsive to debt - and in the current scenario monetary policy continues to target inflation, while transfers policy passively adjusts to stabilize debt. Debt is stabilized when the government's delivered transfers are only a fraction, $\lambda_{t}$, of promised transfers, $z_{t}{ }^{11}$ Transition paths for this policy regime appear as triangles in figure 7. The figure shows paths from 2045 on and repeats the paths in figure 6 , solid lines, for comparison.

When the passive transfers policy is realized, the tax rate is below the fiscal limit, so $\tau_{t}$ jumps immediately to $\tau^{\max }$, creating a surprise increase in the tax rate. This causes a sharp reduction in labor supply, hours worked, and output. Passive transfers implies that the government does not fulfill its promises on transfer payments, as figure 8 shows. The shock of the regime change drives actual transfers to 75 percent of promised and then the fraction smoothly declines as the passive transfers regime continues in effect.

Regime change produces an unexpected drop in inflation, as agents had put a 50 percent chance on going to the passive monetary regime in which inflation is higher. Active monetary

\footnotetext{
${ }^{11}$ Because transfers are lump-sum and $\lambda_{t}$ is endogenous, there is a fundamental indeterminacy between the value of debt at the fiscal limit and the present value of $\lambda_{t} z_{t}$. Given the process for $z_{t}$, for each sequence of $\left\{\lambda_{t} \in[0,1]\right\}_{t=T}^{\infty}$, there is a corresponding value of debt at the limit, $B_{T} / P_{T}$. We resolve this indeterminacy by assuming that the debt-output ratio settles in at 1.08 in the passive transfers regime.
} 

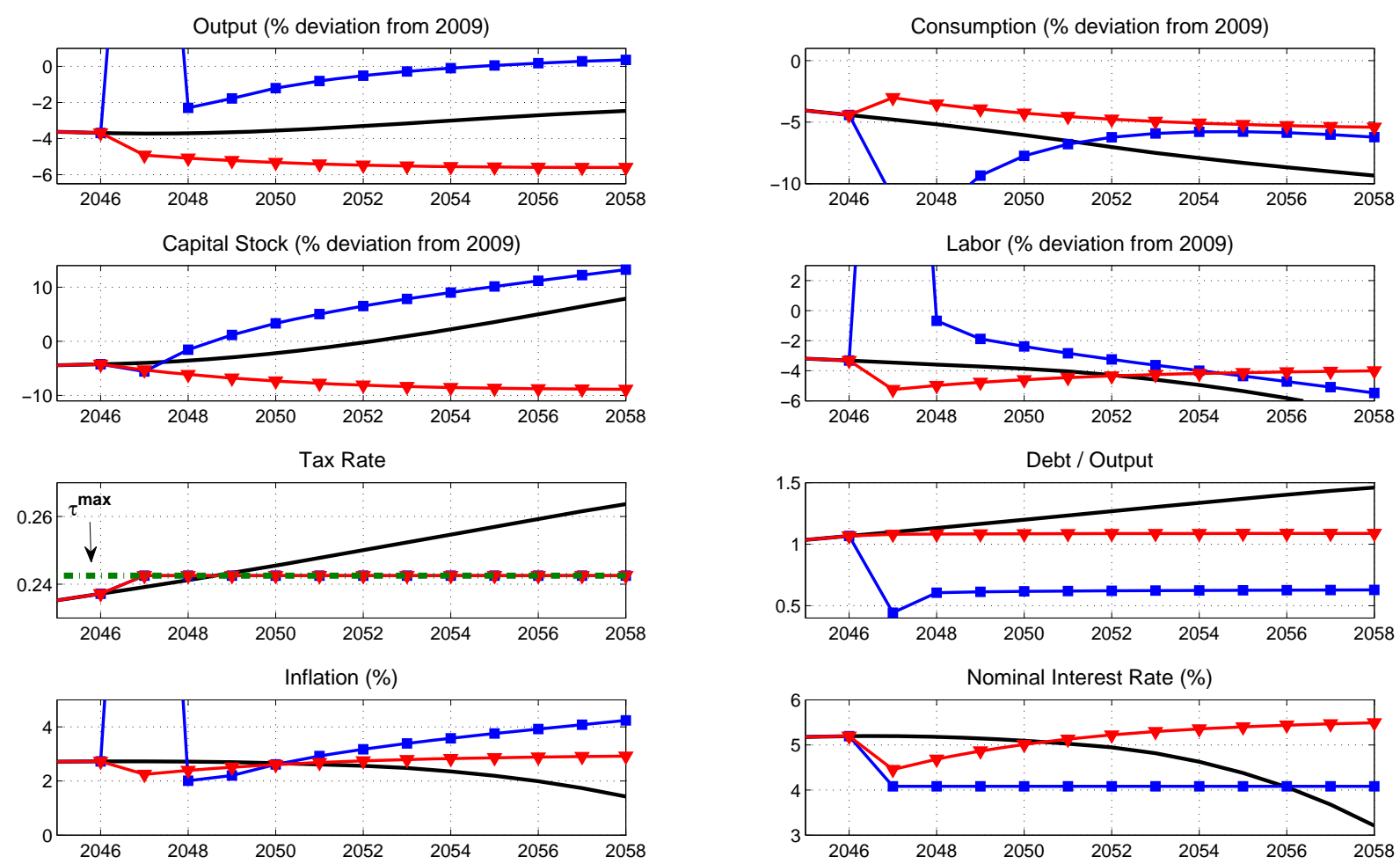

Figure 7: Transition paths for other two regimes superimposed on paths conditional on active monetary, passive tax, and active transfers policies. Active monetary/passive tax/active transfers policies are solid lines; active monetary/active tax/passive transfers policies outcomes are marked by triangles; passive monetary/active tax/active transfers policies outcomes are marked by squares. Large spikes in variables in the passive monetary/active tax/active transfers regime are truncated.

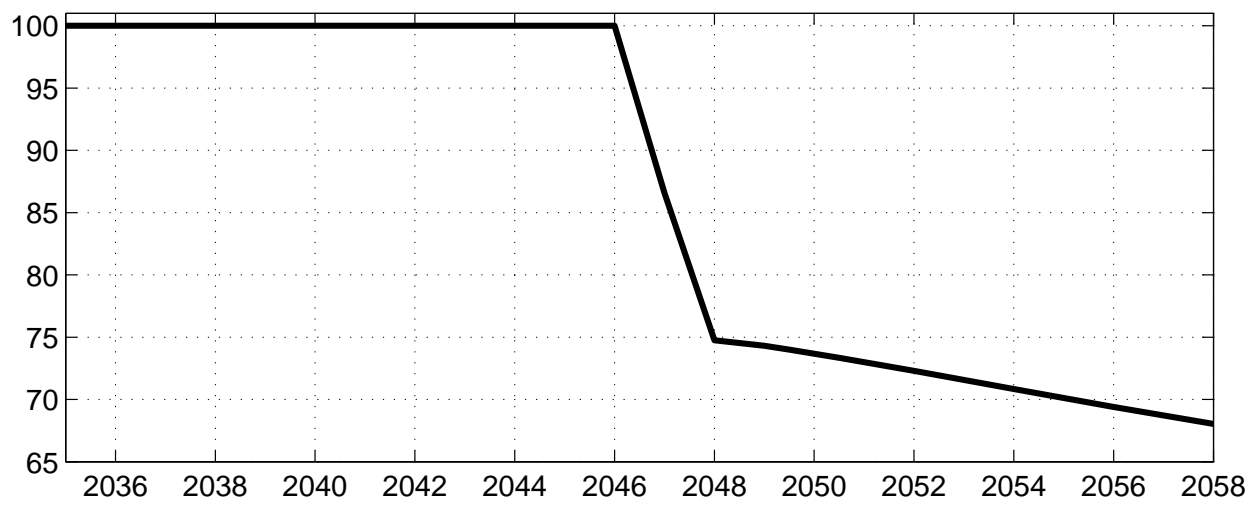

Figure 8: Realized path of $\lambda_{t}$, the percentage of promised transfers that is honored, associated with the counterfactual exercise in figure 7 , which is conditional on active monetary, active tax, and passive transfers policies. 


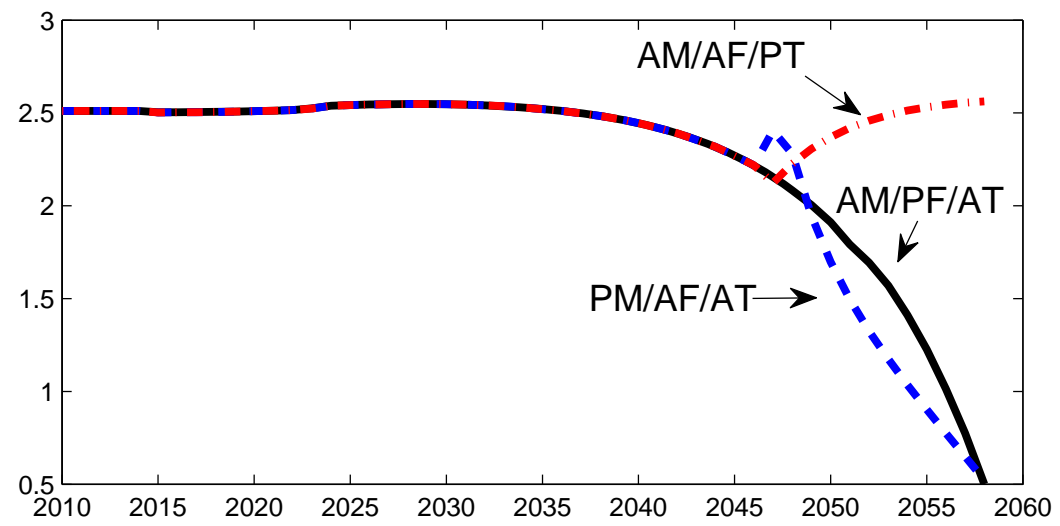

Figure 9: Ex-ante real interest rates in the three regimes. Active monetary/passive tax/active transfers policies are solid line; passive monetary/active tax/active transfers policies are dashed lines; active monetary/active tax/passive transfers policies are dotted-dashed lines.

policy reacts to the drop in inflation by sharply lowering the nominal and the ex-ante real interest rates [dotted dashed line in figure 9]. Despite the decline in output, initially lower real rates raise consumption. As inflation gradually rises, the real interest rate rises, and consumption smoothly declines. Gradually rising inflation stems from agents' beliefs that a switch to passive monetary policy - and the jump in inflation that it engenders - remains a possibility. Even though the passive transfers regime is far more persistent (expected duration of 100 years) than is the passive monetary regime (expected duration of 10 years), as we see below, the jump in inflation that passive monetary policy produces is sufficiently large that its impacts spill into the regime with active monetary and passive transfers policies. Once again we see that the possibility that exploding promised transfers will be realizedcoupled with active monetary policy - prevents the central bank from effectively targeting inflation.

5.1.3 Passive Monetary, Active Tax, And Active Transfers Policies The final scenario has the government delivering on its promised transfers - active policy - while monetary policy abandons its effort to target inflation, reverting instead to pegging the nominal interest rate - passive monetary policy. In this regime, although promised transfers are currently being honored, agents place substantial probability on moving to the regime in which the government will renege. In anticipation of that reneging, agents increase savings dramatically, raising the capital stock well above even its initial 2009 level [marked by squares in figure 7]. The initial jump in the ex-ante real interest rate creates the incentive to increase investment [dashed line in figure 9].

At the time of the regime change there is a huge spike in inflation triggered by a sharp downward revision in the expected present value of primary surpluses. Agents had put 50 percent probability on the passive transfers regime, but the realization of active transfers causes them to revise downward their view of future surpluses. At the price level in place before the regime change, the real value of outstanding nominal debt is now too high to be supported by the new view of the surplus path. This creates a jump in aggregate demand- 
debt is initially overvalued so households seek to reduce their debt holdings - which raises labor demand, hours worked, output, and inflation. Costly price adjustment, however, more than absorbs the additional output, so both investment and consumption fall in the year of the regime change. ${ }^{12}$

Each period that policy remains in the passive monetary/active transfers regime, transfers are unexpectedly high, relative to the expectation of switching to the more persistent active monetary/passive transfers regime, another example of how expectations formation effects flow across regimes. These surprises create a sequence of positive forecast errors in inflation which steadily raise the inflation rate and, with monetary policy pegging the nominal interest rate, reduces ex-post real interest rates. Lower debt service, coupled with the revaluation of outstanding debt, helps to stabilize debt.

Based on the analytical results in section 4, it might seem that this combination of passive monetary/active transfers policies, if it persisted indefinitely, could stabilize debt. That outcome, though, relies on the real interest rate being exogenous. In the more sophisticated model, capital accumulation drives down the real interest rate - see figure 9 - which raises the expected present value of the already explosive transfers process. A higher expected present value of transfers, in turn, raises the expected rate of reneging in the active monetary/passive transfers regime to which agents are expecting to transit in the future. But lower expected future transfers encourages still more capital accumulation and the process repeats. The presence of expectations formation effects, stemming from the prospect of the government possibly reneging on promised transfers, makes the passive monetary/active transfers regime unsustainable in the long run.

In this regime, as in the past two, monetary policy continues to lose control of inflation. As figure 9 shows, the ex-ante real interest rate falls steadily after its initial jump at the time of the regime change. At the same time, though, monetary policy is pegging the nominal interest rate. Expected inflation must be rising. The combination of passive monetary policy with an explosive promised - and honored - transfers process implies that monetary policy not only cannot control actual inflation, but even the pegged nominal interest rate fails to control expected inflation.

5.2 Stationary Distribution of the Economy Figure 10 plots the 25th and 75th percentiles bands (dashed lines) and the 10th and 90th percentiles bands (solid lines) of time paths of variables in the stationary distribution of the economy. The economy was simulated using 10,000 draws, assuming that year 2009 is the zero-shock steady state, stationary transfer regime. The draws represent percentage deviations from the steady state distribution over time. At each date, the figure depicts the cross-sectional distribution of the variables. Several findings emerge.

First, the dispersion in the distribution and the deviation from 2009 levels is very small for the first 10 years (from 2010-2020) for all variables. This result is not entirely inconsistent with CBO projections [Congressional Budget Office (2009a)] and figure 2. According to the $\mathrm{CBO}$, the recovery of the economy and the corresponding increase in tax revenue, coupled with the reduction in non-interest government spending to pre-financial crisis levels (see figure 1), stabilizes debt over the short term. However, the mechanism operating in our model is

\footnotetext{
${ }^{12}$ Introduction of long-term nominal government bonds, along the lines of Cochrane (2001), would mitigate these extreme one-time jumps.
} 

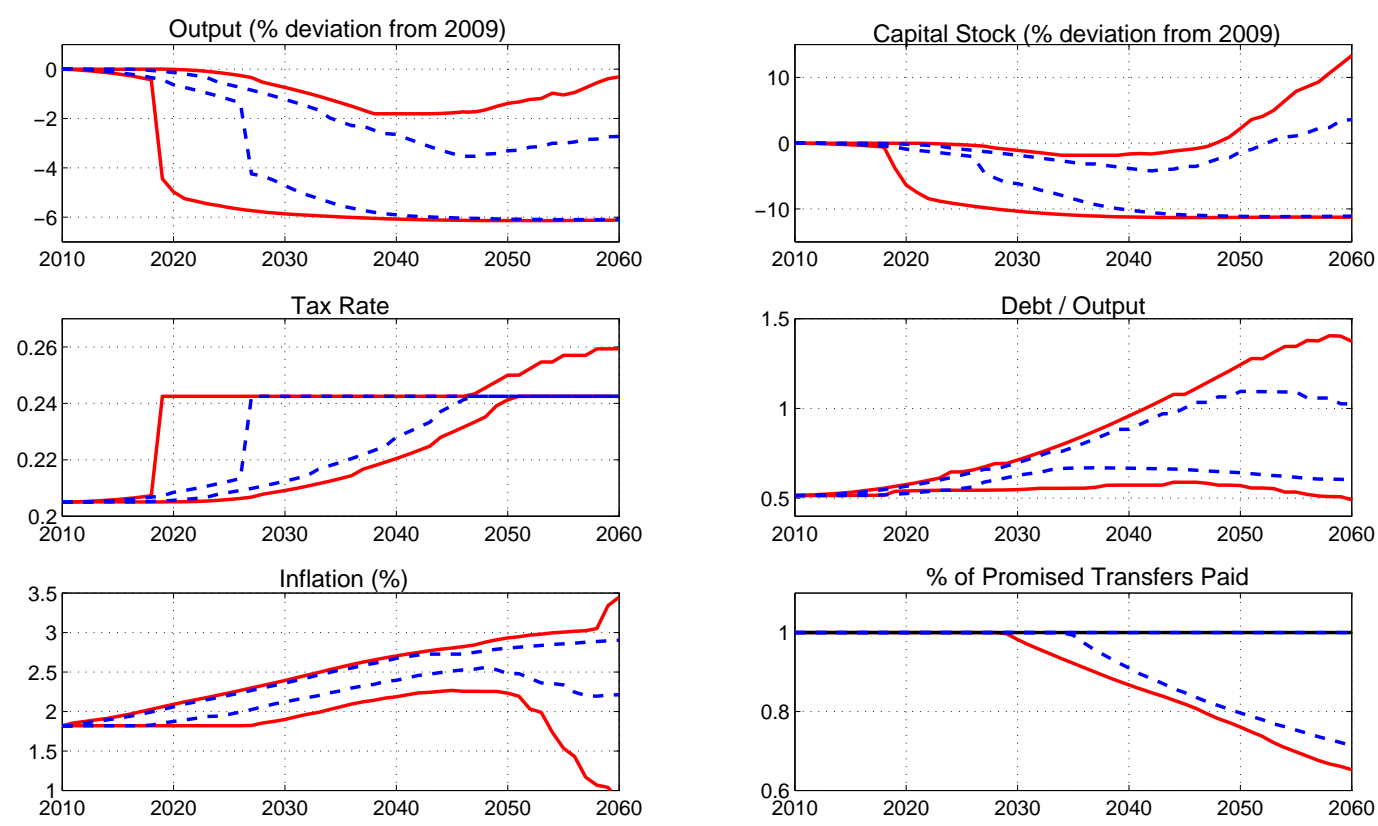

Figure 10: Cross sections of stationary distribution of model variables from monte carlo simulation taking draws from policy regimes. Dashed lines are 25th and 75th percentile bands; solid lines are 10th and 90th percentile bands. Output, consumption, capital stock, and labor are percentage deviations from their 2009 levels. Based on 10,000 draws.

quite different. While there is always a chance of hitting the fiscal limit, the probability of doing so is very small initially (2 percent) and increases only gradually. Agents know that while the process for transfers is unsustainable and a policy adjustment must occur in the future, the future is sufficiently far enough away that the expectational effects associated with policy uncertainty are heavily discounted. This result is, of course, very sensitive to the parameter values of the model. An increase in either the initial probability of hitting the fiscal limit or a steepening of the logistic function so that this probability increases at a faster rate over time, will change this result quantitatively. But qualitatively, the initial impact of "unfunded liabilities" will be small relative to the effects several decades out.

Related to this point, figure 10 shows that the debt/output ratio never reaches 150 percent at any point in time, even for the 90th percentile band. This result is in stark contrast to $\mathrm{CBO}$ projections in figure 2, where the debt-output ratio reaches a maximum of well over 700 percent. As emphasized in the introduction, "unfunded liabilities" that are unsustainable are inconsistent with a rational expectations equilibrium. Assuming that policies adjust to ensure a stationary equilibrium places an upper bound on the debt-output ratio, but quantitatively the upper bound for our calibration only puts the debt-output ratio slightly above that after World War II. Moreover, and quite importantly, this ratio is achieved without a large amount of reneging on promised transfers. Figure 10 shows that most of the probability mass for the promised transfers paid out is greater than 0.8 for the entire time horizon, and there is no reneging at any percentile until 2030. As shown in figure 1 , the calibrated distribution for non-stationary transfers roughly matches the projection of 
the CBO, and assumes real transfers per capita grow at 1 percent per year. Even after the fiscal limit is reached, our model allows for the possibility that promised transfers be paid in full for some time, assuming that monetary policy becomes passive. This mechanism adds an important dimension of reality to the model as policymakers may be reluctant to change popular entitlement programs and avoid the political "third rail." This mechanism explains why the percentage of promised transfers paid is so high.

By leaving the door open for actual transfers to be less than promised, the model does not produce the dire inflationary - or hyperinflationary - scenarios that some observers suggest [Kotlikoff and Burns (2004)]. In figure 10, even the 90th percentile band never exceeds 3.5 percent annual inflation. These bands, though, do not report the one-time spikes that arise when the passive monetary policy regime is realized.

Finally, the monte carlo exercise makes clear the time-varying uncertainty facing the economic agents and the wide range of possible equilibrium outcomes. For example, figure 10 shows that the capital stock may rise or fall over time. An increase in the capital stock is explained by a negative wealth effect operating through expected reneging on transfers. As the probability of hitting the fiscal limit increases, there is an increase in the probability of the reneging regime becoming reality. A precautionary savings result ensues as agents save dramatically to offset the expected decline in transfers. The negative response of capital that shows up as early as 2020 is due to the distorting effects of taxes. Draws of the tax rate in the 90 th percentile spike to $\tau^{\max }$ prior to 2020 because the economy has hit the fiscal limit. This "early" and persistent jump in the tax rate has the usual strong and negative impact on capital formation and output.

\section{Concluding Remarks}

A key element of our analysis, and of any reasonable analysis, of these looming fiscal issues is that future policy is marked by tremendous uncertainty. By taking a stand on the nature of that uncertainty, this paper shows that it is possible to use a rational expectations equilibrium to try to understand how these large fiscal issues will impact the macro economy. This is the paper's primary contribution.

To produce the numerical results we report, we have had to specify parameters describing private and policy behavior. Results are highly sensitive to those parameter settings. The framework the paper develops, however, is general and sufficiently flexible to accommodate alternative specifications on private behavior and the potential range and nature of policy adjustments in the future.

Despite the specificity of the stands we have taken, we are comfortable drawing some broad conclusions:

1. Although the looming fiscal issues are large, they may not produce the "end-of-theworld" scenarios that some commentators have suggested. For example, although in this environment monetary policy can no longer achieve its inflation target, there is no reason to expect a prolonged period of hyperinflation or even extremely high inflation. While it is true that private consumption falls over the coming decades, GDP may not be much lower, and the capital stock could even grow. In such an equilibrium, the degree to which the government reneges on its promised transfers could be quite moderate. 
2. Uncertainty about future policies pushes many of the adjustments of the economy into the future, smoothing out adjustments that take place in the near term. Resolving that uncertainty is likely to bring effects forward in time.

3. When government spending policies push tax policy to the fiscal limit-whether that limit be economic or political-monetary policy loses control of inflation. Analyses of monetary policy going forward must come to terms with this reality.

We have considered only a small set of possible policy scenarios. Many other scenarios are possible. It is a worthwhile research program to examine other scenarios and trace out their likely consequences for the macro economy.

This paper has performed no welfare analysis and does not examine distributional issues. But the framework certainly points toward a research program that aims to design and evaluate monetary and fiscal rules that can both cope with the coming fiscal issues and reduce uncertainty about future policy. Of course, the political process - like research economistsmust ultimately take a stand on how to resolve America's fiscal problems. 


\section{A APPENDiX}

A.1 Details About Figures 1 and 2 Figure 2 plots the actual and projected debt-toGDP ratio from 1790 through 2083. The dashed lines represent CBO projections [Congressional Budget Office (2009b)] under two scenarios - the Alternative Fiscal Financing (AF) and Extended-Baseline scenario (EB). The difference between the two forecasts is that the EB projection assumes current law does not change, while the AF allows for "policy changes that are widely expected to occur and that policymakers have regularly made in the past," [Congressional Budget Office (2009b)]. The prominent changes include: [i] assuming the expiring tax provisions in the Economic Growth and Tax Relief Reconciliation Act of 2001 and the Jobs and Growth Tax Relief Reconciliation Act of 2003 will be extended beyond 2010; [ii] assuming the Alternative Minimum Tax will be indexed to inflation; [iii] assuming physician payment rates under Medicare will grow at the same rate as the Medicare economic index.

A.2 Numerical Solution Method We solve the model using the monotone map method from Coleman (1991). The algorithm is as follows:

1. Discretize the state space around the nonstochastic steady state for each state variable (i.e. $\left.\Theta_{t}=\left\{K_{t-1}, z_{t}, b_{t-1}, R_{t-1}, m_{t-1}, S_{z, t}, S_{t}\right\}\right)$.

2. Conjecture an initial set of decision rules for the capital stock, labor, marginal costs and inflation. We initially solved a simplified version of the model with stationary transfers and either AM/PF or PM/AF policy. We then used weighted combinations of these rules as the initial conjectures. Denote the initial rules as $\widehat{h}_{j}^{K}\left(\Theta_{t}\right)=K_{t}, \widehat{h}_{j}^{N}\left(\Theta_{t}\right)=N_{t}, \widehat{h}_{j}^{\psi}\left(\Theta_{t}\right)=\psi_{t}$ and $\widehat{h}_{j}^{\pi}\left(\Theta_{t}\right)=\pi_{t}$ for $j=0$. We can then define decision rules for the other endogenous variables using resource constraints.

3. At each point in the state space, substitute these decision rules into the household's first-order necessary conditions. In turn, the $t+1$ dated endogenous variables depend on $\Theta_{t+1}$. Numerical integration is used then to integrate over the exogenous variables $z_{t+1}, S_{z, t+1}$ and $S_{t+1}$. For a given point on the state space, this procedure yields a nonlinear system of equations. Solving this system for state variables at each point in the state space yields updated values for the decision rules (e.g. $\left.\widehat{h}_{j+1}^{K}\left(\Theta_{t}\right)=K_{t}\right)$. Note that the time $t$ solution for the system is used to construct the state vector for $t+1$.

4. Repeat step (3) until the decision rules converge at every point in the state space $\left(\left|\widehat{h}_{j}^{K}\left(\Theta_{t}\right)-\widehat{h}_{j+1}^{K}\left(\Theta_{t}\right)\right|<\epsilon\right)$.

As evidence of local uniqueness, we perturb the converged decision rules in various dimensions and check that the algorithm converges back to the same solution. We restrict our attention to solutions on the minimum set of state variables. The only channel for states outside of the minimum set to matter is through expectation formation, so introducing additional states would require a solution method that allows latitude to specify how the extraneous states affect expectations. Given there is no theory to guide such decisions in the current setting, the discipline imposed by focusing on the minimum set of state variables and the monotone map algorithm is appealing.

The monotone map computes a solution using only first-order necessary conditions, so does not formally impose transversality conditions. In the present context, the transversality condition plays a key role because it prevents the government from perpetually rolling over government debt. To gain insight into this issue, we solved simpler models using the mono- 
tone map that explicitly violated the transversality condition. The algorithm converged in these cases; however, the resulting simulations imply non-stationary paths for debt. Conversely, models that satisfied the transversality condition implied stable debt dynamics. As a numerical check of the transversality condition, we simulated the model 5,000 times - randomly drawing from policy regimes - and computed the average debt level at each date. We found that after 46 periods the expected value of debt peaks at roughly 80 percent of output, indicating that the expected value of debt does not asymptotically explode. ${ }^{13}$

\footnotetext{
${ }^{13}$ We cannot run simulations out for, say, 10,000 periods as a check of the transversality condition because the promised transfer process is nonstationary. Given that promised transfers are a state variable, the approximate solution will become increasingly inaccurate as the equilibrium dynamics drift further off the grid.
} 


\section{REFERENCES}

Abel, A. B., And O. Blanchard (1983): "An Intertemporal Equilibrium Model of Saving and Investment," Econometrica, 1(2), 675-692.

Aguiar, M., and G. Gopinath (2006): "Defaultable Debt, Interest Rates and the Current Account," Journal of International Economics, 69(1), 64-83.

Arellano, C. (2008): "Default Risk and Income Fluctuations in Emerging Economies," American Economic Review, 98(3), 690-712.

Auerbach, A. J., J. Gokhale, and L. J. Kotlikoff (1994): "Generational Accounting: A Meaningful Way to Evaluate Fiscal Policy," Journal of Economic Perspectives, 8(1), 7394.

(1995): "Restoring Generational Balance in U.S. Fiscal Policy: What Will It Take?," Federal Reserve Bank of Cleveland, 31(1), 3-12.

Auerbach, A. J., and K. Hassett (1992): "Tax Policy and Business Fixed Investment in the United States," Journal of Public Economics, 47, 141-170.

- (2007): "Optimal Long-Run Fiscal Policy: Constraints, Preferences, and the Resolution of Uncertainty," Journal of Economic Dynamics and Control, 31(5), 1451-1472.

Auerbach, A. J., And L. J. Kotilikoff (1987): Dynamic Fiscal Policy. Cambridge University Press, Cambridge, M.A.

Bi, H. (2009): "Sovereign Risk Premia, Fiscal Limits and Fiscal Policy," Manuscript, Indiana University.

Bizer, D. S., And K. L. Judd (1989): "Taxation and Uncertainty," American Economic Review, 79(2), 331-336.

Bütler, M. (1999): "Anticipation Effects of Looming Public-Pension Reforms," CarnegieRochester Conference Series on Public Policy, 50, 119-159.

Chari, V. V., P. J. Kehoe, and E. R. McGrattan (2000): "Sticky Price Models of the Business Cycle: Can the Contract Multiplier Solve the Persistence Problem?," Econometrica, 68(5), 1151-1179.

Cochrane, J. H. (1999): "A Frictionless View of U.S. Inflation," in NBER Macroeconomics Annual 1998, ed. by B. S. Bernanke, and J. J. Rotemberg, vol. 14, pp. 323-384. MIT Press, Cambridge, MA.

- (2001): "Long Term Debt and Optimal Policy in the Fiscal Theory of the Price Level," Econometrica, 69(1), 69-116.

Coleman, II, W. J. (1991): "Equilibrium in a Production Economy with an Income Tax," Econometrica, 59(4), 1091-1104. 
Congressional Budget Office (2002): A 125-Year Picture of the Federal Government's Share of the Economy, 1950 to 2075. CBO, Washington, D.C.

(2009a): An Analysis of the President's Budgetary Proposals for Fiscal Year 2010. CBO, Washington, D.C., June.

- (2009b): The Long-Term Budget Outlook. CBO, Washington, D.C., June.

Davig, T., And E. M. Leeper (2006): "Fluctuating Macro Policies and the Fiscal Theory," in NBER Macroeconomics Annual 2006, ed. by D. Acemoglu, K. Rogoff, and M. Woodford, vol. 21, pp. 247-298. MIT Press, Cambridge. 607-635.

Dotsey, M. (1990): "The Economic Effects of Production Taxes in a Stochastic Growth Model," American Economic Review, 80(5), 1168-1182.

Hall, R. E. (1971): "The Dynamic Effects of Fiscal Policy in an Economy with Foresight," Review of Economic Studies, 38(2), 229-244.

Hassett, K., and G. Metcalf (1999): "Investment with Uncertain Tax Policy: Does Random Tax Policy Discourage Investment," The Economic Journal, 109(457), 372-393.

İmrohoroĞLu, A., S. İmrohoroĞLu, and D. H. Joines (1995): "A Life Cyle Analysis of Social Security," Economic Theory, 6(1), 83-114.

Kotlikoff, L. J., And S. Burns (2004): The Coming Generational Storm: What You Need to Know About America's Economic Future. MIT Press, Cambridge, MA.

Kotlikoff, L. J., K. Smetters, and J. Walliser (1998): "The Economic Impact of Transiting to a Privatized Social Security System," in Redesigning Social Security, ed. by H. Siebert, p. 327. Kiel University Press, Kiel.

— (2007): "Mitigating America's Demographic Dilemma by Pre-Funding Social Security," Journal of Monetary Economics, 54(2), 247-266.

Leeper, E. M. (1991): “Equilibria Under 'Active' and 'Passive' Monetary and Fiscal Policies," Journal of Monetary Economics, 27(1), 129-147.

Mendoza, E. G., And V. Z. Yue (2008): "A Solution to the Default Risk-Business Cycle Disconnect," NBER Working Paper No. 13861.

North, D. C. (1990): Institutions, Institutional Change, and Economic Performance. Cambridge University Press, Cambridge.

O'NeILl, J. E. (1996): "CBO Testimony: The Long-Run Budgetary Impacts of an Aging Population," Statement before the Committee on the Budget, U.S. House of Representatives, Congressional Budget Office, March 13. 
Peter G. Peterson Foundation (2009): State of the Union's Finances: A Citizen's Guide. www.pgpf.org, March.

Rotemberg, J. J. (1982): "Sticky Prices in the United States," Journal of Political Economy, 90(December), 1187-1211.

Rotemberg, J. J., And M. Woodford (1997): "An Optimization-Based Econometric Framework for the Evaluation of Monetary Policy," in NBER Macroeconomics Annual 1997, ed. by B. S. Bernanke, and J. J. Rotemberg, vol. 12, pp. 297-346. MIT Press, Cambridge, MA.

SAnger, D. E. (2010): "Long-Term Debt. Obama Budget Sees Years of Deficits, A Test of U.S. Power and Political Will," New York Times, February 2, 2010, p. A1.

Sargent, T. J. (2006): "Ambiguity in American Monetary and Fiscal Policy," Japan E⿱ The World Economy, 18(3), 324-330.

Sargent, T. J., And N. Wallace (1981): "Some Unpleasant Monetarist Arithmetic," Federal Reserve Bank of Minneapolis Quarterly Review, 5(Fall), 1-17.

Sims, C. A. (1994): "A Simple Model for Study of the Determination of the Price Level and the Interaction of Monetary and Fiscal Policy," Economic Theory, 4(3), 381-399.

Smetters, K., And J. Walliser (2004): "Opting Out of Social Security," Journal of Public Economics, 88(7-8), 1295-1306.

Woodford, M. (1995): "Price-Level Determinacy Without Control of a Monetary Aggregate," in Carneige-Rochester Conference Series on Public Policy, vol. 43 of CarnegieRochester Conference Series on Public Policy, pp. 1-46. North-Holland.

\section{University Press, Princeton, N.J.}

